NBER WORKING PAPER SERIES

\title{
WHAT DO PEOPLE BUY \\ WHEN THEY DON'T BUY HEALTH INSURANCE AND WHAT DOES THAT SAY ABOUT WHY THEY ARE UNINSURED?
}

\author{
Helen Levy \\ Thomas DeLeire \\ Working Paper 9826 \\ http://www.nber.org/papers/w9826
NATIONAL BUREAU OF ECONOMIC RESEARCH
1050 Massachusetts Avenue
Cambridge, MA 02138
July 2003

\begin{abstract}
We thank Vanessa Coca for excellent research assistance. For helpful comments and discussions, we thank Eric Engen, Louise Sheiner and Larry Levitt, as well as seminar participants at Georgetown, Rutgers, the University of Maryland, the University of Chicago, RAND, and the National Bureau of Economic Research. DeLeire thanks the Center for Human Potential at the Irving B. Harris Graduate School of Public Policy Studies and Levy thanks the California HealthCare Foundation for financial support of this project. The California HealthCare Foundation, based in Oakland, California, is a non-profit philanthropic organization whose mission is to expand access to affordable, quality health care for underserved individuals and communities, and to promote fundamental improvements in the health status of the people of California. The views expressed herein are those of the authors and not necessarily those of the National Bureau of Economic Research
\end{abstract}

(C2003 by Helen Levy and Thomas DeLeire. All rights reserved. Short sections of text not to exceed two paragraphs, may be quoted without explicit permission provided that full credit including (C) notice, is given to the source. 
What Do People Buy When They Don't Buy Health Insurance And

What Does that Say about Why They Are Uninsured?

Helen Levy and Thomas DeLeire

NBER Working Paper No. 9826

July 2003

JEL No. Z1

\begin{abstract}
$\underline{\text { ABSTRACT }}$
Using data from the 1994 through 1998 Consumer Expenditure Surveys, we compare household spending on 16 different goods (food at home, food away from home, housing, transportation, alcohol and tobacco, interest, furniture and appliances, home maintenance, clothing, utilities, medical care, health insurance, entertainment, personal care, education, and other) for insured versus uninsured households, controlling for total expenditures and demographic characteristics. The analysis shows that the uninsured in the lowest quartile of the distribution of total expenditures spend more on housing, food at home, alcohol and tobacco, and education than do the insured. In contrast, households in the top quartile of the distribution of total expenditures spend more on transportation and furniture and appliances than do comparable insured households. These results are consistent with the idea that poor uninsured households face higher housing prices than do poor insured households. Further research is necessary to determine whether high housing prices can help explain why some households do not have insurance.
\end{abstract}

Helen Levy

Harris School of Public Policy Studies

University of Chicago

1155 E $60^{\text {th }}$ Street

Chicago, IL 60637

and NBER

hlevy@uchicago.edu
Thomas DeLeire

Kennedy School of Government

Harvard University

79 John F. Kennedy Street

Cambridge, MA 02138

t-deleire@uchicago.edu 


\section{Introduction}

Surprisingly little research has used an economic framework to analyze why some households do not have health insurance. Most of the literature on the uninsured emphasizes the demographic characteristics of the uninsured, rather than the economic constraints and choices that determine coverage. Since the purchase of health insurance is voluntary, coverage represents a tradeoff for households between insurance and other goods. The economics of this tradeoff are governed by income, prices and preferences. In this framework, understanding why people are uninsured means knowing to what extent each of these factors is responsible for the failure to purchase insurance.

The design of appropriate public policy toward the uninsured depends critically on understanding the relative importance of these three factors. Suppose, for example, that the main reason some households do not have health insurance is that their incomes are low and they place basic needs like food and shelter ahead of health insurance. The debate about covering the uninsured in this situation is fundamentally one about equity and redistribution; there is no market failure. If government intervention is called for, the appropriate policy response is to redistribute resources to the poor through either cash or in-kind transfers.

Alternatively, suppose that most of the uninsured do not buy insurance because information asymmetries in the insurance market mean that they face actuarially unfair prices. Government intervention that corrects this market failure will increase social welfare. This inefficiency can be addressed using the same regulatory tools that are applied to the market for automobile insurance: mandates to purchase coverage combined with government-sponsored pools to insure high-risk individuals. Proposals to mandate coverage also typically include 
subsidies to low-income households, suggesting that policymakers believe some combination of prices and incomes to be responsible for the lack of health insurance coverage.

Another way in which price differences may help explain lack of insurance coverage is if the uninsured face higher prices than the insured for other goods. For example, suppose that some households face higher housing prices than do others. If housing is inelastically demanded with respect to its own price, spending on housing will increase in response to higher housing prices. This price increase will also reduce spending on health insurance if the compensated cross-price elasticity is either negative or positive but smaller than the income effect associated with the price increase: that is, the two goods may be gross complements. To put it even more simply, the high cost of housing may squeeze health insurance out of the household's budget. If this is the reason why some households are uninsured, it is not obvious what policy response is most appropriate. Clearly, regulation of health insurance markets misses the point. Income redistribution or policies directed at the housing market would be more likely to affect the number of uninsured in this case.

If prices and income cannot explain why some households do not have insurance, the only remaining explanation that economists have to offer is that preferences must differ. For example, one explanation for the fact that some households buy health insurance and some do not is differences in risk aversion. Households may also differ in their preferences for other goods; some households may choose private schools for their children, annual family vacations, or nicer homes over having health insurance. If differences in preferences are responsible for variations in insurance coverage, it is not clear that any policy intervention is justified. ${ }^{1}$ Moreover, it can be difficult to distinguish differences in preferences from differences in prices. 
For example, is living in a city and facing high housing prices as a result a reflection of preferences, or an exogenous difference in prices? Stigler and Becker (1977) have argued that it is, in general, impossible to distinguish analytically between these two possibilities; any hypothesized difference in preferences can be modeled as a difference in prices. Therefore we should consider carefully any reasonable explanation that relies on income or prices to explain variation in insurance coverage, relying on differences in preferences only as the explanation of last resort.

Our goal in this paper is to provide preliminary evidence on the relative importance of income, prices, and preferences in explaining the fact that some households are uninsured. We begin by showing that even within quite narrow income categories, the fraction of households purchasing insurance is seldom close to either one or zero. We conclude that income cannot be the whole story for why some households are uninsured.

To shed light on whether prices or preferences can explain the remaining variation in insurance coverage, we compare the consumption patterns of uninsured households to those of insured households with similar total expenditures and other characteristics. The logic behind this exercise is that we can infer from these patterns how prices facing the insured and uninsured would have to differ if they were to explain the observed differences in spending between the two groups and assess whether the hypothesized price differences seem plausible. Moreover, while the prices individual households face are difficult to observe directly, we have very good data on household spending patterns.

Our comparison of spending patterns reveals that uninsured households, on average, spend more than comparable insured households on transportation, furniture and appliances,

\footnotetext{
${ }^{1}$ An exception is when we believe there are significant externalities associated with the lack of insurance. In this case, as above, some combination of mandates and subsidies would address the externality without imposing unfair
} 
education, and alcohol and tobacco. Since most uninsured households are low income, more interesting results emerge when we compare insured versus uninsured households in the bottom quartile of the expenditure distribution. ${ }^{2}$ Uninsured households in this group devote significantly more of their budgets than do the insured to housing, food at home, education, and alcohol and tobacco. As we will explain in more detail later, these results are consistent with the idea that the uninsured face higher prices for these goods, in particular housing. Moreoever, controlling for homeownership - which is likely to be a proxy for housing prices - cuts the uninsured differential in housing spending in half, lending further support to the idea that the uninsured may face higher housing prices than the insured.

Returning to the question we posed at the outset: do income, prices or preferences explain the fact that some households do not have health insurance? Clearly, income matters: health insurance is a normal good. But it is not the only thing that matters. Our analysis of spending patterns suggests that the prices of other goods - most notably housing - may be additional important factors causing some households not to purchase health insurance. In future work, we plan to use data on housing prices to quantify more precisely the magnitude of this effect relative to the effect of income or preferences, in order to help inform public policy. Our results in this paper suggest that policies focusing only on the market for health insurance may be insufficient to address the problem of the uninsured.

costs on low-income households.

${ }^{2}$ We use total expenditures, rather than income, to describe households' economic status because expenditures are likely to be a better measure of permanent income than is annual income (for further discussion of this issue, see Rogers and Gray [1994]). 


\section{Background}

There is a considerable literature on the demographic correlates of health insurance. A recent report by the Institute of Medicine (2001) reviews this literature and also presents new analyses confirming what earlier studies have shown: the probability of being uninsured is higher for individuals who are poor, less well-educated, nonwhite, and/or in families without a worker. In addition to studies that take a demographic approach to analyzing the determinants of coverage, a number of recent studies also suggest that private coverage responds at the margin to economic incentives. For example, Cooper and Schone (1997) and Farber and Levy (2000) both document that the decline in employer-sponsored coverage during the late 1980s and early 1990s was due to declines in enrollment among eligible employees. Cutler and Gruber (1996) show that the Medicaid expansions during the same period caused a decline in private coverage. Rask and Rask (2000) and Herring (2001) both show that private coverage rates respond to the availability of charity care in a community. All of these studies suggest that - as we might expect in a voluntary system - having coverage or not is the result of a sequence of rational economic decisions.

As we have already mentioned, in a simple economic model the amount of a good purchased is determined by income, prices (of all goods), and preferences. Several papers address either explicitly or implicitly the importance of income in determining whether or not a household has insurance coverage. In addition to the Institute of Medicine (IOM) report discussed above, Thomas (1994/95) estimates the marginal increase in the probability of having insurance as income rises; she concludes that the income threshold above which families are likely to purchase health insurance is $125 \%$ of poverty. Her estimates show that about half of families just below this threshold purchase insurance. Bundorf and Pauly (2000) also estimate 
the marginal impact of income on the probability of coverage, using more narrowly defined income categories than does Thomas. Their results show the probability of coverage increasing more or less continuously with family income. This is prima facie evidence that income is not the sole determinant of coverage; if it were, we would expect a sharp discontinuity in the probability of having health insurance at some threshold level of income. Yegian et al. (2000) note that about 40 percent of the uninsured are above twice the poverty level and report results from a survey of California's nonpoor uninsured population. Interestingly, although 60 percent of respondents agree with the statement "I worry a lot about not having health insurance for others in my family," only 41 percent agree that "health insurance ranks very high on my list of priorities for where to spend my money." Since these families are all above twice the poverty level, the implication again is that being above poverty is insufficient to ensure the purchase of health insurance.

A number of other studies explore how prices affect health insurance coverage. Before considering the results of these studies, it is worth noting a few important distinctions. The first is between the price of health insurance and the price of other goods. Without exception, existing studies of the relationship between prices and health insurance coverage focus on the price of health insurance. The second distinction, which applies to discussions of the price of health insurance, is between prices that are actuarially unfair and prices that are actuarially fair but high relative to income. With one exception which we discuss below, existing studies of prices and health insurance discuss prices in the second sense. That is, they consider whether the overall increase in the level of health insurance prices helps explain the overall decline in coverage, rather than whether information asymmetries in the insurance market cause some consumers to drop out of the market. The third and final set of distinctions concerns how to 
measure the overall 'price' of health insurance. Is the correct measure of price the expected benefit or the administrative load on that benefit? Is it the employee's share of the premium or the total premium? This issue is discussed at length by Chernew, Cutler and Keenan (2002); we do not discuss this issue here except to note that it is a point of debate in this area of the literature.

Several studies examine the relationship between the price of health insurance and coverage. Most of these estimate the own-price elasticity of takeup of coverage offered by an employer, rather than the relationship between health insurance prices and the overall rate of insurance coverage. An exception is the study by Chernew, Cutler and Keenan (2002), who find only a weak negative relationship between changes in the overall cost of health insurance and rates of health insurance coverage at the MSA level. The estimates of takeup elasticities are generally also quite low; Chernew, Frick and McLaughlin (1997) and Gruber and Washington (2003) conclude that because of these low elasticities, premium subsidies to workers have only limited potential to increase coverage rates. Cutler (2002) also finds a low elasticity of takeup but points out that combined with large increases in employee premium contributions, this effect can explain the entire decline in take-up of employer-sponsored insurance during the 1990s.

Only the paper by Cardon and Hendel (2001) addresses the question of whether prices in the market for health insurance are actuarially unfair and therefore potentially responsible for the fact that some people do not buy insurance. Cardon and Hendel conclude that there is no evidence of adverse selection. Evidence on the role of price of health insurance - in either sense - in determining insurance coverage is therefore mixed.

There are to our knowledge no studies that have looked at how the price of other goods affects the probability of insurance coverage. As a review of why this is relevant, consider how 
the demand for good $Y_{2}$ is in theory affected by the price of another good $Y_{1}$. The cross-price version of the Slutsky equation summarizing this relationship, with income denoted by $m$, is:

$$
\frac{\partial Y_{2}}{\partial p_{1}}=-Y_{1} \cdot \frac{\partial Y_{2}}{\partial m}+\left.\frac{\partial Y_{2}}{\partial p_{1}}\right|_{U=\bar{U}}
$$

This cross-price effect has two components. The first term - the income effect associated with the change in the price of $Y_{1}$ - reduces the consumption of $Y_{2}$ as long as $Y_{2}$ is a normal good (by definition). The second term - the compensated substitution effect - may be either positive (the goods are net substitutes) or negative (the goods are net complements). Provided the compensated substitution effect is negative or, if positive, is at least smaller in absolute value than the income effect, demand for $Y_{2}$ will decrease in response to an increase in the price of $Y_{1}$. That is, the goods may be gross substitutes even if they are not net substitutes. Put even more simply, an increase in the price of one good may "squeeze out" some spending on another. We are interested in exploring whether this phenomenon may help explain why some households do not have insurance.

To summarize, our reading of the existing literature suggests three things: first, that income alone cannot explain the fact that some households have health insurance and some do not. Second, that the evidence on the role of the price of health insurance in explaining lack of health insurance coverage is mixed. Third, although there has been no work attempting to determine how the prices of other goods affect health insurance coverage, simple economic theory predicts that they should matter. One of our goals in looking at the consumption patterns of insured and uninsured households is to try to understand whether higher prices of other goods may help explain why some households do not have health insurance. 


\section{Methods}

Our main analysis relies on a comparison of the spending patterns of uninsured households with insured households that are comparable in terms of demographics and total spending. Specifically, we estimate multivariate regressions controlling for household composition and demographics. For each of the sixteen expenditure categories, we estimate a separate linear regression with the household's spending in that category as the dependent variable:

$$
Y_{j}=X \beta_{j}+\gamma \cdot(\text { uninsured })+\delta \cdot(\text { total spending })+S T A T E+\left(y_{1994}+\ldots+y_{1998}\right)+\varepsilon_{j}
$$

where $j$ indexes the 16 expenditure categories, $X$ is a vector of demographic controls, uninsured is a dummy variable equal to one if the household has no health insurance, STATE is a

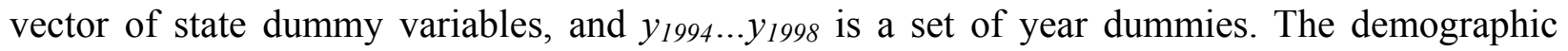
controls we use are race (white, non-white) of the head, educational attainment of the head (indicator variables for being a high school dropout, being a high school graduate, having some college, or being a college graduate), age of the head, the number of male adults in the family, the number of female adults in the family, the number of boys (ages 2 to 17) in the family, the number of girls (ages 2 to 17) in the family, and the number of infants. The coefficient $\gamma$ on the uninsured dummy measures the average difference in spending on good $j$ for an uninsured compared to an insured household. To focus on households that must choose between paying for private insurance and being uninsured, we drop households where anyone has public insurance from the sample. We also drop households in which some members have private insurance and some are uninsured. We describe exactly how the sample is drawn in section four.

These regressions allow us to identify which goods take up more of an uninsured household's budget than an insured household's. In order to see how this may help shed light on 
whether prices or preferences explain why one household has health insurance and another with the same total budget does not, we review the relationship between prices and spending. Consider a consumer with income $m$ who allocates this income to $n$ goods $X_{1}, \ldots, X_{n}$ and faces a vector of prices $p_{1}, \ldots p_{n}$. Expenditures on good $j$ are given by $X_{j} p_{j}$. If the price of good 1 increases, the expenditure on good 1 may increase or decrease depending on the own-price elasticity of demand for good 1 :

$$
\frac{\partial\left(X_{1} p_{1}\right)}{\partial p_{1}}=X_{1}+p_{1} \cdot \frac{\partial d X_{1}}{\partial p_{1}}=X_{1} \cdot\left(1+\eta_{x_{1}, p_{1}}\right) .
$$

So if $X_{1}$ is inelastically demanded (that is, $\left|\eta_{x_{1}, p_{1}}\right|<1$ ), the amount spent on $X_{I}$ increases with the price of $X_{1}$. Suppose we observe uninsured households spending more than insured households on good $X_{1}$ (holding total spending and other household characteristics constant). If we are to conclude that this spending differential occurs because the insured and the uninsured face different prices, it must be that $X_{I}$ is inelastically demanded with respect to its own price and the uninsured face higher prices than the insured. ${ }^{3}$

\section{Data}

The data we analyze are from the 1994 through 1998 panels of the Consumer Expenditure Survey (CEX). The CEX, which is collected by the Census Bureau under contract from the Bureau of Labor Statistics, is a nationally representative survey of about 7,000 households per year. It contains information on the demographic characteristics of each household member and

\footnotetext{
${ }^{3}$ Alternatively, this could happen if demand for $X_{1}$ were elastic and the uninsured faced lower prices than the insured. We do not focus on this possibility since the uninsured facing lower prices than the insured for other goods ought to increase their health insurance spending (unless there are very strong patterns of net substitution between health insurance and other goods).
} 
detailed household-level information on income, expenditures and health insurance. In the CEX, a "consumer unit" or family is the basic unit of observation. A consumer unit is smaller than a "household" and is meant to include only those household members who depend upon one another and who share expenditures. For details of the distinction between a consumer unit and a household in the CEX, please see BLS (2002). ${ }^{4}$ In this paper, we use the terms family and household interchangeably. Each household is interviewed up to four times at three-month intervals. Three months of expenditure data are collected retrospectively at each quarterly interview for a total of twelve months of expenditure data.

\section{Preliminary sample restrictions}

We begin with 39,617 households interviewed in the 1994 through 1998 panels of the CEX. For each household, we have between one and four observations on quarterly expenditures in each of these categories. We average quarterly expenditures over however many observations are available so that there is one observation per household for each expenditure category. Medical care and housing expenditures in a given quarter may be negative (because of reimbursements or refunds). We drop from the sample 345 households that have negative average quarterly expenditures in one or both of these categories, 471 households with missing income data and 47 households without adults, resulting in a sample of 38,754 households.

\footnotetext{
${ }^{4}$ According to the BLS, a consumer unit consists of any of the following: (1) All members of a particular household who are related by blood, marriage, adoption, or other legal arrangements; (2) a person living alone or sharing a household with others or living as a roomer in a private home or lodging house or in permanent living quarters in a hotel or motel, but who is financially independent; or (3) two or more persons living together who use their incomes to make joint expenditure decisions. Financial independence is determined by the three major expense categories: Housing, food, and other living expenses. To be considered financially independent, at least two of the three major expenditure categories have to be provided entirely or in part by the respondent. In regard to the CEX, the BLS uses the terms consumer unit, family, and household interchangeably for convenience. However, the proper technical term in the CEX is consumer unit (BLS 2002).
} 


\section{Defining the uninsured}

Each household in the CEX reports the total number of health insurance policies held by anyone in the household in each quarter, and the number of household members covered by each policy. It is not possible to identify which individuals in a household are covered (either as dependents or as the policyholder) by a particular private policy. Each household also reports which individuals were covered by Medicare and/or Medicaid. We categorize households as uninsured, partially insured, fully insured, covered by Medicaid or covered by Medicare according to the insurance status of all members of the household at the first quarter in which the household is observed, as follows:

- Households that do not report holding any private insurance policies and have zero expenditure on health insurance are considered to be uninsured.

- Households that report holding a private insurance policy or policies that cover some but not all household members and report zero expenditure on health insurance are considered partially insured.

- Households that report holding one or more private insurance policies that cover at least as many people as there are in the household or who report any positive expenditures on health insurance are considered fully insured.

- Households with at least one member covered by Medicaid and no one covered by Medicare are considered covered by Medicaid (even if some or all members of the household also have private insurance). 
- Households with anyone covered by Medicare, or in which the reference person is age 65 or older, are considered covered by Medicare (even if some or all members of the household also have private insurance).

Households may change insurance status across waves. We discard the 2,623 households that do so, leaving us with a sample of 36,131 households; our results are very similar if instead we categorize household on the basis of their insurance status at the first interview.

\section{Expenditure categories}

The CEX gathers data on expenditures in hundreds of detailed categories. We aggregate these detailed expenditures into 16 broad expenditure categories: (1) food to be consumed in the home, (2) food to be consumed outside of the home (at restaurants etc.), (3) alcohol and tobacco, (4) housing expenses (rent and renting-related expenses, mortgage and mortgage related expenses, and home improvements), (5) non-mortgage interest, (6) furniture, appliances and related expenses, (7) home maintenance, (8) clothing (adult clothing and shoes, children's clothing and shoes, and clothing services), (9) transportation (car purchases, car leases, other private transportation expenses, fuel, car repairs, car insurance, public transportation expenses), (10) utilities, (11) medical care, (12) health insurance, (13) entertainment expenses, (14) personal care, (15) education, and (16) other. Note that each of these categories includes expenditures made by the household members only - in particular, expenses made on behalf of households members by insurance companies or employers are not reflected in these data. This means that medical care and health insurance reflect out-of-pocket payments only.

The CEX measures expenditures and not consumption. Expenditures may be a noisy measure of consumption - for example, where a family occupies public housing. In addition, 
there is topcoding for some expenditure items. In order to minimize measurement error associated with these factors, we trim the top and bottom 5 percent of spenders in our sample. This does not appreciably change the substance of our results and leaves a sample of 32,519 households. Of these, about one-third are either partially insured or publicly insured: 2 percent partially insured, 7 percent Medicaid, 25 percent Medicare. We drop these households from the analysis. ${ }^{5}$ Our analysis focuses on the remaining 4,682 uninsured households and 16,842 fully privately insured households, to whom we refer from now on as "the uninsured" and "the insured," respectively.

\section{Measurement error in health insurance and medical care spending}

Since the CEX collects data on out-of-pocket spending only, both health insurance and medical care spending are certain to be mismeasured for the insured because of employer-paid health insurance premiums and direct payments from insurers to medical providers. This has two implications for our analysis. First, the observed spending differentials in these two categories between the insured and the uninsured will understate the true difference in spending. As long as we are primarily interested in other categories of spending (e.g., food and housing), this just means that we should keep in mind that the estimated differentials for health insurance and medical care are likely to be understated. Second, and more seriously, our measure of total spending will be systematically underestimated for the insured but not for the uninsured. This has the potential to bias our estimates of the insured/uninsured differential on other categories of spending, like food and housing. This is because we are effectively comparing a richer insured

\footnotetext{
${ }^{5}$ The regression results do not change much if the partially insured are included with the fully insured. They are also robust to categorizing households on the basis of reported policies only (i.e. households with a policy that covers only some household members and positive health insurance spending are counted as partially insured).
} 
household with a poorer uninsured household, even though both have the same observed total spending.

To bound the magnitude of this bias, we calculate an alternative set of estimates as follows. Since workers directly pay, on average, only about 20 percent of health insurance premiums with firms paying the remainder on their behalf (Krueger and Levy 1996), we assume that total health insurance spending would actually be five times what we observe for each household in the CEX. We re-estimate all the regressions using this alternative measure of health insurance spending and the higher level of total spending it implies. This adjustment does not substantially affect any of the results of the analysis presented below, so we conclude that the understatement of health insurance and total spending for the insured is unlikely to be a significant source of bias.

\section{Results}

We begin our empirical analysis by stratifying the sample by total spending and calculating the fraction with private health insurance at each spending level. These results are presented in table $1 .{ }^{6}$ Consistent with the results of earlier work discussed above, we find that the fraction with health insurance increases fairly smoothly with income. Moreover, even at the ends of the distribution, the fraction with insurance is not close to zero or one. Among the poorest two percent of households in our sample, 30 percent have private health insurance, and seven percent of households in the top fifth of the expenditure distribution are uninsured. The point here is that there does not appear to be a level of income that functions as a cutoff above

\footnotetext{
${ }^{6}$ All of the statistics and analyses we present have been weighted using the sampling weights provided with the CEX so as to be nationally representative.
} 
which everyone has private insurance and below which no one does, so income alone cannot explain why some households are uninsured.

Table 2 presents statistics on demographic and household composition by insurance status. Comparing mean values of the household demographic characteristics for the different groups reveals that uninsured households have lower total expenditures than fully insured households: uninsured households have mean quarterly expenditures of only $\$ 5,077$, compared with $\$ 8,050$ for fully insured households. Household heads in uninsured households have lower educational attainment than the heads of insured households; 22 percent of uninsured household heads are high school dropouts, compared with only 8 percent in fully insured households. They are also more likely to be nonwhite (19.8 percent for uninsured versus 13.0 percent for fully insured).

Differences in employment and homeownership are more pronounced. Uninsured households are more than twice as likely as fully insured households to have no earner (8.4 percent versus 3.0 percent). Note, however, that this still means that the vast majority of the uninsured are in households with at least one worker. Conditional on having an earner, heads in uninsured households are less likely to work in the public sector (8.8 percent versus 13.7 percent) and more likely to be self-employed ( 8.6 percent versus 4.2 percent) than are heads in fully insured households. The most striking difference, however, may be that the uninsured are nearly twice as likely to be renters: 61.8 percent of the uninsured rent their homes, compared with only 33.4 percent of the fully insured. To the extent that these household characteristics drive spending patterns, it will be important to control for them in our analysis in order to understand the differences between the spending of the insured and the uninsured. 
Table 3 shows mean budget shares and mean real expenditures (in 1998 dollars) for all households by insurance status. The three largest expenditure categories for both insured and uninsured households are housing, food at home, and transportation. Insured households spend just over three percent of their budgets, or $\$ 236$ per quarter, on health insurance (recall that this amount does not reflect payments made directly by an employer to an insurance company on the household's behalf).

Comparing budget shares across insurance status reveals that the uninsured spend a larger share of their budgets on food at home (16.9 percent) than the fully insured (12.8 percent). The uninsured also spend a larger share on housing: 26.6 percent versus 25.4 percent for the fully insured. The uninsured spend a substantially smaller share of their budgets on transportation (15.7 percent versus 17.2 percent for the fully insured). Out-of-pocket medical care expenses account for a slightly larger share of budgets for the insured (3.8 percent versus 1.9 percent for the uninsured). ${ }^{7}$

As we have already noted, insured and uninsured households do not differ only in their health insurance status. As a first cut at comparing uninsured households with similar insured households, we calculate mean expenditure shares separately for insured and uninsured households in the lowest quartile ("low spenders"), the middle 50 percent ("middle spenders"), and the top quartile of total expenditures ("high spenders"). The results are presented in table 4. Among low spenders, the uninsured spend a larger fraction of their budgets on housing than do the insured (28.2 percent compared with 26.1 percent), on food at home (19.5 percent compared with 16.5 percent), and on education (3.5 percent compared with 2.4 percent). Low-spending uninsured households also spend a larger share of their budgets on alcohol and tobacco (4.4

\footnotetext{
${ }^{7}$ Paulin and Weber (1995) report similar differences in spending patterns between insured and uninsured and uninsured households in the 1993 Consumer Expenditure Survey.
} 
percent compared to 3.3 percent) than do insured households. On average, the low-spending uninsured spend $\$ 126$ per quarter on alcohol and tobacco, which is more than the $\$ 119$ that their insured counterparts spend out-of-pocket on health insurance. This is not to suggest that uninsured households could actually purchase health insurance with the amount they currently spend on alcohol and tobacco - as we have already noted, most health insurance premiums are paid by employers, so that the actual price of health insurance per quarter is more likely to be about $\$ 595$ per quarter for these households.

At the same time, low-spending uninsured households spend a smaller share of their budgets on categories other than health insurance. The low-spending uninsured spend significantly less on interest, home maintenance, transportation, utilities, health care and personal care than do insured households with similar total expenditures.

The differences between spending patterns of the insured versus the uninsured are much smaller for high spenders. In particular, the only categories on which uninsured high-spenders spend a significantly larger share of their budgets than do insured high-spenders are alcohol and tobacco $(0.017$ versus 0.014$)$, transportation $(0.320$ versus 0.239$)$, furniture and appliances (0.063 versus 0.054$)$ and education $(0.035$ versus 0.030$)$. This is a striking contrast to the result reported above for low-spending households; the differences between insured and uninsured households' consumption patterns are very different for poorer versus well-off households.

\section{Regression Results}

Of course, the insured and the uninsured differ in many ways other than total spending; for example, as shown in table 2, the uninsured have lower educational attainment and are more likely to be non-white. In order to control for total spending as well as these observable 
differences, we run multivariate regressions to estimate adjusted differences in spending using the methods described above. Table 5 presents the coefficients on the "uninsured" dummy variable from separate regressions (for each of the sixteen expenditure categories) corresponding to equation (1) for all households. ${ }^{8}$ The coefficient on this "uninsured" dummy variable measures the average difference in spending between insured and uninsured households for that expenditure category.

It is not obvious whether controls for employment, urban location and homeownership ought to be included in these regressions, since all three of these characteristics could be considered household consumption choices. One person might choose to own a home in Ithaca, NY, for example, while another person with the same total budget might choose to rent an apartment in Manhattan. ${ }^{9}$ Since it is not clear whether including these controls is appropriate, we present results corresponding to three different specifications. The first specification includes only basic controls - age, sex, race and education of the household head, and the number of adult males, adult females, girls, boys and infants in the household and year and state dummies. The second specification adds to these basic controls dummy variables reflecting whether a household has zero, one, or two or more earners; the sector of employment of the primary earner (private, public, self-employed, or unknown/no primary earner); and a set of dummies reflecting whether the household lives in a Metropolitan Statistical Area (MSA) and whether the household lives in an urban area. The third specification includes, in addition to the basic, employment, and urbanicity controls, controls for homeownership. The homeownership controls consist of dummies for whether the household owns a home without a mortgage, owns a home with a

\footnotetext{
${ }^{8}$ The complete set of results (that is, the coefficients on the independent variables in addition to the "uninsured" dummy) corresponding to the basic regression in column one of table 5 is reported in Table A1 of the appendix.
} 
mortgage, rents, occupies a home rent-free, or lives in dormitory. Columns (1), (2), and (3) of table five report the linear regression results for the specifications including basic, employment and urbanicity, and homeownership controls respectively.

Since the results in table 4 suggested that the difference between insured and uninsured households may look different depending on how well-off the households are, we also stratify the sample by total spending and estimate complete sets of regressions on each subsample. Tables 6, 7 and 8 present results of these regressions for households in the lowest quartile ("low spenders"), middle fifty percent ("middle spenders"), and top quartile ("high spenders") of the total spending distribution respectively.

Since more than half of the uninsured households in our sample $(2,403$ out of 4,682$)$ are low spenders, we begin by focusing on our results for this group, presented in table six. These results confirm that for the low-spending households, the mean differences between uninsured and insured households that were reported in table four persist when we control for a basic set of household characteristics. In particular, according to the linear regression results, the uninsured spend significantly more than do insured households on housing $(\$ 88)$, on food at home $(\$ 40)$, on education (\$35) and on alcohol and tobacco (\$20). These results confirm that low-spending uninsured households spend more on basic needs, plus alcohol and tobacco. The uninsured also spend significantly less than the insured on several items besides health insurance: interest (\$24 less), utilities (\$22 less), home maintenance (\$10 less), and personal care (\$4 less). Figure two summarizes these differentials graphically.

What do these spending differentials suggest about whether the low-spending uninsured may face higher prices than the insured for goods other than health insurance? Consider the

\footnotetext{
${ }^{9}$ One might argue that education and family composition are consumption choices as well. In practice, controlling for these variables (the basic regression specification) yields the same qualitative result as the simple differences in
} 
largest differential, the $\$ 88$ more per quarter the uninsured spend on housing. Since housing is inelastically demanded with respect to its own price (Hanushek and Quigley [1980]), the higher housing expenditures of the uninsured are consistent with their facing higher prices for housing. Alternative explanations for this differential include that the uninsured consume more or better housing. We present evidence below that the uninsured do not consume more housing. Further support for the idea that the uninsured may, in fact, face higher housing prices comes when we add controls for housing tenure to the regression. The addition of employment and urbanicity controls does not change the regression-adjusted estimates of the differences in spending between insured and uninsured households; adding the homeownership controls, in contrast, eliminates more than half of the difference in housing and home maintenance expenditures and all of the difference in expenditures on utilities between insured and uninsured households. Thus, the results for the low-spending uninsured (representing more than half the total uninsured in our sample) raise the interesting possibility that high housing prices may partially explain the fact that these households do not have health insurance.

The differential between insured and uninsured middle-spending households look somewhat different from those just discussed for the low-spending households. Among middle spenders, uninsured households spend significantly more than insured households on transportation (\$172), education (\$101), food at home (\$31), and alcohol and tobacco $(\$ 25)$. Adding controls for employment, urbanicity and housing tenure reduces some of these differentials a bit (in particular, the education differential drops to $\$ 68$ and the alcohol/tobacco differentials drops to $\$ 14$ ), but all remain significant. What is most interesting about these results is that in contrast to the low-spending uninsured, who spent more than their insured counterparts on a good that is demanded inelastically, the middle-spending uninsured spend more on goods

mean budget shares in Table 5 . 
that are likely to be demanded elastically: education and transportation. This means that higher prices of goods other than health insurance are not a plausible explanation for lack of insurance coverage in this group.

The regression results for high spenders illustrate this point even more clearly. The only two categories on which high-spending uninsured spend more than their comparable insured households are transportation (\$673) and furniture/appliances (\$102). As long as these goods are demanded elastically with respect to price, higher spending suggests that if the uninsured face different prices from the insured these prices must be lower and therefore cannot explain why the uninsured do not have health insurance. In common sense terms, it simply does not sound plausible to suggest that the well-off uninsured do not buy health insurance because of the high cost of transportation and furniture.

Thus, analysis of spending patterns of the well-off uninsured does not offer plausible candidates for goods other than health insurance that might help explain why these households do not buy health insurance. Two possibilities remain. One is that the well-off uninsured face higher prices of health insurance than the well-off insured. We have no way to test this possibility with these data. Alternatively, we might conclude that the well-off uninsured simply have different preferences than the well-off insured. If this latter explanation is correct, as we have already noted, it is not obvious what role there is for policy intervention.

\section{Detailed Analyses of the Housing Expenses of Low-Spending households}

The CEX data allow us to analyze the differences in housing spending for low-spending insured and uninsured households in more detail. We have already demonstrated that the inclusion of controls for housing tenure "explains" about half of the spending differential in the 
sense that it drops from $\$ 88$ to $\$ 38$ in magnitude. We can also use more disaggregated data to see exactly which components of housing expenditure are higher for the uninsured and to see whether the uninsured consume more housing than the insured. Table 9 presents descriptive statistics on components of housing expenditure and housing characteristics for low-spending insured and uninsured households. The first two row of table 9 shows that uninsured households spend a larger share of their budgets and a larger real dollar expenditure on housing than do insured households - this is the same information reported in table 4. An examination of the components of housing expenditure shows that this difference in total expenditure is being driven primarily by differences in rent, which is the largest single component of housing expenditure. Table 9 also shows that on average, the uninsured do not consume a larger quantity of housing when quantity is defined as number of rooms: the uninsured living in housing units with 4.3 rooms on average compared with 4.7 for the insured.

To control for differences in homeownership status (though not other observable differences between the insured and the uninsured), table 10 presents the same statistics on detailed housing expenditures by insurance status separately for homeowners without a mortgage, homeowners with a mortgage, and renters. Among homeowners with no mortgage, there are no differences between the housing expenditures of insured and uninsured. Similarly, among renters, uninsured households do not have higher expenditures. In fact, uninsured renters spend \$104 less per quarter than do insured renters. There are differences in expenditure between insured and uninsured households among homeowners with a mortgage. Thus, the overall differences in housing expenditure between insured and uninsured households are primarily due to differences in homeownership status, plus slightly higher expenditure among uninsured homeowners with mortgages. 
Table 11 reports the coefficient on the "uninsured" dummy variable from a set of linear regressions with the components of housing expenditure as the dependent variables. As in tables 5 through 8 , the three columns correspond to specifications with basic controls (first column), plus controls for employment and urbanicity (second column) and plus controls for homeownership (third column). As we expect given the findings reported in table 10, the addition of homeownership controls eliminates almost all of the differences between insured and uninsured households not only for total housing expenditure but also for each of the components of housing expenditure.

\section{Detailed Analysis of the Transportation Expenses of High-Spending Households}

The fact that high-spending uninsured households spend a larger share of their budgets on transportation than do high-spending insured households raises two questions: first, what particular transportation expense is driving these differences? Second, is this result driven by the fact that some households are incorrectly classified as "high spenders" by a one-time purchase of a durable good like a car? To address the first question, table 12 reports the breakdown of average transportation expenditures for insured and uninsured households into detailed components. It appears that the differences between the insured and uninsured are primarily in spending on used cars. Table 12 also shows that the uninsured do not have a larger stock of vehicles than the insured; the uninsured have on average 2.2 vehicles compared with 2.7 for the insured. Table 13 reports regression-adjusted estimates of these differentials that support the same conclusion: the difference between transportation spending of insured and uninsured households is due to used cars. The inclusion of additional controls for employment, urbanicity and housing tenure has almost no effect on the estimated difference. 
Table 13 also presents regression results that use household income rather than total expenditures as a control in the regressions to address the possibility that houses are being misclassified as high spenders by a transitory spike in spending due to the purchase of a car. The last three columns of table 13 contain these results. It appears that the use of expenditures rather than income does explain some (not quite half) of the difference in spending between the insured and uninsured. Using income as a control, the regression-adjusted estimate of the differential is between $\$ 289$ (including all controls) and $\$ 430$ (basic controls only), compared with $\$ 457$ (all controls) to $\$ 673$ (basic controls) when including total expenditures instead of income. The differentials remain significant, however.

\section{Discussion}

We have documented that there are differences in the spending patterns of insured and uninsured households, and also that the spending differentials are quite different for lowspending versus high spending households. For low-spending households, expenditures of the uninsured relative to the uninsured are tilted primarily toward housing and food; for high spenders, the differential is transportation and furniture/appliances. At what level of spending does this crossover occur? To answer this question, we aggregate expenditures into two categories: basic needs and non-basic needs. We consider food at home, housing, and utilities to be basic needs; all other expenditures are non-basic. The first row of table 14 reports the fraction of our sample that is insured, and share of total spending allocated to basic needs for both the insured and uninsured. The uninsured spend, on average, 54 percent of their budget on basic needs compared with 48 percent for the insured. Of course, the main reason for this is that uninsured households are poorer than insured households, on average, and basic needs are 
necessities. This can be seen in the first two columns of Table 14 which report the cumulative fractions of the entire sample and the uninsured sample by expenditure level: the median household has quarterly total expenditures between $\$ 6,500$ and $\$ 7,000$ while the median uninsured household has quarterly total expenditures between $\$ 4,000$ and $\$ 4,500$.

The fourth and fifth columns of Table 14 report the share of households' budgets that are spent on basic needs at a variety of total expenditure levels. For example, uninsured households with quarterly total expenditures of less than $\$ 2,000$ spend 60.4 percent of their budgets on basic needs compared with 50.4 percent for comparable insured households. At what level of quarterly total expenditure do uninsured households begin to spend less on basic needs than comparable insured households? At a quarterly total expenditure of about $\$ 6,500$, both uninsured and insured households spend about 50 percent of their budgets on basic needs. At all levels of total expenditure below $\$ 6,500$ per quarter, uninsured households spend more on basic needs than do insured households. Moreover, 76.8 percent of uninsured households have quarterly total expenditure levels of $\$ 6,500$ or less. Therefore, one could consider about threequarters of the uninsured as falling below a spending level where insurance is in a very loose sense being "replaced" by spending on basic needs.

A regression-based approach to the same question is the following. We estimate the share of spending devoted to basic needs as a function of total expenditures, a dummy for uninsurance and total expenditures interacted with a dummy for uninsurance, controlling for demographics and household composition. This regression captures the relationship between spending on basic needs and total expenditures for insured and uninsured households; figure 5 depicts this relationship graphically. The idea is that at low levels of total expenditure, uninsured households spend more on basic needs than do insured households, while at higher levels of total 
expenditure, uninsured households do not spend more on basic needs than do insured households. We want to know at what implied level of total spending an uninsured household spends less on basic needs than do insured households. In figure 5, this level of total expenditure is given by $\mathrm{Y}^{*}$, where the two lines intersect.

The results of this regression are presented in table 15. The coefficient on the uninsured dummy is 0.08365 ; the coefficient on total expenditures is -0.000019 and the coefficient on the interaction of uninsured with total expenditures is -0.000011 . This means that at low levels of expenditure, the uninsured spend a higher fraction of their budgets on basic needs, but that this differential gets smaller as total expenditure increases. At a total expenditure of $\$ 7,594$ per quarter, the uninsured begin spending a smaller share of their budgets on basic needs than do the insured at the same level of total expenditure. That is, the value of $\mathrm{Y}^{*}$ in figure 5 implied by this regression is $\$ 7,594$. Eighty-four percent of uninsured households fall below this threshold. Of course, 53 percent of households with insurance also fall below this threshold.

Our definition of "basic needs" is arbitrary. An alternative way to do this is to use the economic definition of necessities versus luxuries. We estimate total expenditure elasticities for each category of consumption and determine that the following expenditures are empirically necessities (i.e. they have total expenditure elasticity of less than or equal to one; results are in appendix Table A2): food at home, utilities, health insurance, alcohol and tobacco, personal care, housing, interest, food away from home, and clothing. Using this definition to aggregate expenditures into necessities (except for health insurance) and luxuries, we find very similar results to those using the "basic needs" dependent variable. These results also are reported in table 15 . We estimate that at total expenditures of $\$ 7,032$, uninsured households begin spending 
less on necessities than do insured households. Eighty percent of uninsured households and 47 percent of insured households fall below this threshold.

\section{Conclusion}

Our main results and their implications for future research on the uninsured can be summarized as follows. First, we find that income cannot be the whole story for why some households do not have health insurance: the probability of coverage increases more or less continuously with income. This result has appeared in the literature but it is worth emphasizing that this means low income cannot be the only explanation for lack of coverage. Second, we find that low-income uninsured households - comprising most of the uninsured - spend more than comparable insured households on some necessities and, in particular, on housing. This raises the intriguing possibility, which we plan to explore in future work, that high housing prices may help explain why some households do not have health insurance. Third, high-income uninsured households have higher spending only on transportation and furniture/appliances. This suggests it is highly unlikely that price differentials for goods other than health insurance (such as housing, food, utilities, or transportation) explain why they are uninsured. Instead, either preferences or high prices of health insurance must explain the lack of insurance coverage for a small but nontrivial fraction of well-off households.

What are the implications for policy? Firm recommendations for policy await more conclusive results on the role of health insurance prices versus housing prices in explaining lack of insurance coverage among the low-spending insured. But we believe that our preliminary results should add two new dimensions to policy discussions about the uninsured. First, heterogeneity within the population without health insurance highlights the dangers of treating 
"the uninsured" as a single group. Our results for low-spending uninsured households are quite different from those for high-spending uninsured households. High-spending uninsured households are a minority of the uninsured (about ten percent) but represent a nontrivial number of households: about four million. It may make more sense in thinking about public policy to focus on the needs of the poor uninsured than simply the uninsured. Second, when we think about why households are uninsured, the discussion should be extended beyond income and the price of health insurance to include a role for the prices of other goods. Our results strongly suggest a role for housing prices in explaining why some uninsured households lack coverage. Modeling health insurance coverage as economic choice that requires weighing all possible uses for income will help us better understand the choices households do - or don't - make 


\section{References}

Bureau of Labor Statistics, U.S. Department of Census. 2002. Consumer Expenditure Survey: Frequently Asked Questions. http://www.bls.gov/cex/csxfaqs.htm\#q3, last modified Feb 22.

Cardon, James and Igal Hendel. 2001. "Asymmetric Information in Health Markets: Evidence from the National Medical Expenditure Survey," RAND Journal of Economics 32(2): 408-427.

Chernew, Michael, David Cutler and Patricia Seliger Keenan 2002. "Rising Health Care Costs and the Decline in Insurance Coverage." Manuscript.

Chernew, M.E., Frick, K. and C.G. McLaughlin. 1997. "The Demand for Health Insurance by Low Income Workers: Can Reduced Premiums Achieve Full Coverage?” Health Services Research: 32(4):453-470.

Chollet, Deborah. 2000. "Consumers, Insurers, and Market Behavior," Journal of Health Politics, Policy and Law (30).

Coate, Stephen. 1995. "Altruism, the Samaritan's Dilemma, and Government Transfer Policy," American Economic Review 85(1): 46-57.

Cooper, Philip F., and Barbara Schone. 1997. "More Offers, Fewer Takers for EmploymentBased Health Insurance: 1987 and 1996." Health Affairs (November/ December): 142-149.

Cutler, David and Jonathan Gruber. 1996. "Does Public Insurance Crowd Out Private Insurance?" Quarterly Journal of Economics 111(2): 391-430.

Cutler, David. 2002. "Employee Costs and the Decline in Helath Insurance Coverage." National Bureau of Economic Research Working Paper 9036.

Farber, Henry S. and Helen Levy. 2000. "Recent Trends in Employer-Sponsored Health Insurance Coverage: Are Bad Jobs Getting Worse?” Journal of Health Economics 19(1):93-119.

Gruber, Jonathan and Alan Krueger. 1991. "The Incidence of Mandated Employer-Provided Insurance," in Tax Policy and the Economy, vol. 5, National Bureau of Economic Research, 111143.

Gruber, Jonathan and Ebonya Washington. 2003. "Subsidies to Employee Health Insurance Premiums and the Health Insurance Market," National Bureau of Economic Research Working Paper 9567.

Hanushek, Eric A. and John M. Quigley."What is the Price Elasticity of Housing Demand?" The Review of Economics and Statistics, Vol. 62, No. 3. (Aug., 1980), pp. 449-454.

Herring, Bradley. 2001. "Does Access to Charity Care for the Uninsured Crowd Out Private Health Insurance Coverage?" Working Paper, Yale University. 
Krueger, Alan B. and Helen Levy. 1996. "Accounting for the Slowdown in Employer Health Care Costs," Proceedings of the National Tax Association, Eighty-Ninth Annual Conference (1996), pp. 61-75.

Mills, Robert. J. 2000. “Health Insurance Coverage: 2001,” Current Population Reports P60-220, US Census Bureau.

Pauly, Mark V. and M. Kate Bundorf. 2000. Is Health Insurance Affordable for the Uninsured? Manuscript.

Rogers, John M. and Maureen B. Gray. 1994. "CE data: quintiles of income versus quintiles of outlays," Monthly Labor Review (117):12.

Shore-Sheppard, Lara, Thomas Buchmueller, and Gail Jensen. 2000. "Medicaid and Crowding Out of Private Insurance: A Re-examination Using Firm-Level Data." Journal of Health Economics (19)1: 61-91.

Stigler, George J. and Gary S. Becker 1977. "De Gustibus Non Est Disputandum," American Economic Review, Vol. 67 (2) pp. 76-90.

Thomas, Kathleen. 1994/95. “Are Subsidies Enough to Encourage the Uninsured to Purchase Health Insurance? An Analysis of Underlying Behavior.” Inquiry 31: 415-424.

Yegian, Jill M., David G. Pockell, Mark D. Smith, and Eleanor K. Murray. 2000. "The Nonpoor Uninsured in California, 1998." Health Affairs 19(4): 171 - 177. 
Table 1

Fraction of households with insurance, by total spending

\begin{tabular}{rcc}
\hline & $\begin{array}{c}\text { Sample fraction } \\
\text { in cell: }\end{array}$ & $\begin{array}{c}\text { Fraction } \\
\text { insured: }\end{array}$ \\
Total & 1.000 & 0.779 \\
& & \\
$\$ 2,000$ & 0.020 & 0.303 \\
$\$ 2,500$ & 0.039 & 0.437 \\
$\$ 3,000$ & 0.046 & 0.485 \\
$\$ 3,500$ & 0.057 & 0.568 \\
$\$ 4,000$ & 0.058 & 0.645 \\
$\$ 4,500$ & 0.059 & 0.675 \\
$\$ 5,000$ & 0.055 & 0.737 \\
$\$ 5,500$ & 0.056 & 0.795 \\
$\$ 6,000$ & 0.055 & 0.793 \\
$\$ 6,500$ & 0.049 & 0.820 \\
$\$ 7,000$ & 0.048 & 0.847 \\
$\$ 7,500$ & 0.046 & 0.840 \\
$\$ 8,000$ & 0.041 & 0.887 \\
$\$ 8,500$ & 0.038 & 0.877 \\
$\$ 9,000$ & 0.034 & 0.909 \\
$\$ 9,500$ & 0.033 & 0.888 \\
$\$ 10,000$ & 0.029 & 0.915 \\
$\$ 10,500$ & 0.024 & 0.898 \\
$\$ 10,500+$ & 0.213 & 0.926 \\
\hline
\end{tabular}

Total sample size is 21,524 households. 
Table 2

Household characteristics by insurance status

\begin{tabular}{|c|c|c|}
\hline Basic control variables & Insured & Uninsured \\
\hline Age of Reference Person & 40.4 & 34.9 \\
\hline Family size & 2.6 & 2.3 \\
\hline Number of Adult Males & 0.944 & 0.884 \\
\hline Number of Adult Females & 0.969 & 0.807 \\
\hline Number of Boys & 0.303 & 0.256 \\
\hline Number of Girls & 0.298 & 0.265 \\
\hline Number of Babies & 0.073 & 0.068 \\
\hline Non-white & 0.13 & 0.198 \\
\hline H.S. Dropout & 0.082 & 0.215 \\
\hline H.S. Graduate & 0.29 & 0.313 \\
\hline Some College & 0.301 & 0.329 \\
\hline College Graduate & 0.206 & 0.101 \\
\hline Graduate degree & 0.12 & 0.043 \\
\hline Female Reference Person & 0.343 & 0.387 \\
\hline Total real expenditures & $\$ 8,050$ & $\$ 5,077$ \\
\hline \multicolumn{3}{|c|}{ Employment and urbanicity variables } \\
\hline No earner & 0.030 & 0.084 \\
\hline One earner & 0.416 & 0.602 \\
\hline Two earners or more & 0.554 & 0.314 \\
\hline Primary earner is private sector & 0.814 & 0.801 \\
\hline Primary earner is public sector & 0.137 & 0.088 \\
\hline Primary earner is self-employed & 0.042 & 0.086 \\
\hline DK sector of primary earner & 0.007 & 0.024 \\
\hline Non-MSA, rural & 0.058 & 0.056 \\
\hline Non-MSA, urban & 0.031 & 0.039 \\
\hline Non-MSA, DK urbanicity & 0.118 & 0.160 \\
\hline MSA, urban & 0.331 & 0.343 \\
\hline MSA, DK urbanicity & 0.463 & 0.401 \\
\hline \multicolumn{3}{|l|}{ Housing variables } \\
\hline Own home, no mortgage & 0.486 & 0.185 \\
\hline Own home, with mortgage & 0.153 & 0.108 \\
\hline Rent & 0.334 & 0.618 \\
\hline Occupy home rent-free & 0.016 & 0.047 \\
\hline Live in dormitory & 0.01 & 0.041 \\
\hline Sample n & 16,842 & 4,682 \\
\hline
\end{tabular}


Table 3

Expenditures by insurance status

\begin{tabular}{|c|c|c|c|c|c|c|}
\hline Share spent on: & Mean & $\underline{\mathrm{SD}}$ & Mean & $\underline{\mathrm{SD}}$ & & \\
\hline Housing & 0.254 & 0.135 & 0.266 & 0.155 & -0.012 & $<0.0001$ \\
\hline Food In & 0.128 & 0.069 & 0.169 & 0.106 & -0.041 & $<0.0001$ \\
\hline Food Out & 0.050 & 0.044 & 0.052 & 0.061 & -0.003 & 0.0172 \\
\hline Transportation & 0.172 & 0.143 & 0.157 & 0.153 & 0.015 & $<0.0001$ \\
\hline Utilities & 0.095 & 0.051 & 0.104 & 0.074 & -0.009 & $<0.0001$ \\
\hline Furniture/Appliances & 0.047 & 0.061 & 0.043 & 0.070 & 0.004 & $<0.0001$ \\
\hline Clothing & 0.040 & 0.036 & 0.038 & 0.047 & 0.002 & 0.0229 \\
\hline Entertainment & 0.038 & 0.041 & 0.031 & 0.046 & 0.008 & $<0.0001$ \\
\hline Health Insurance & 0.032 & 0.039 & 0.000 & 0.000 & 0.032 & $<0.0001$ \\
\hline Health Care & 0.024 & 0.038 & 0.019 & 0.048 & 0.005 & $<0.0001$ \\
\hline Education & 0.024 & 0.065 & 0.036 & 0.105 & -0.012 & $<0.0001$ \\
\hline Alcohol and Tobacco & 0.023 & 0.033 & 0.037 & 0.053 & -0.014 & $<0.0001$ \\
\hline Home Maintenance & 0.021 & 0.044 & 0.011 & 0.036 & 0.010 & $<0.0001$ \\
\hline Interest & 0.016 & 0.026 & 0.010 & 0.025 & 0.005 & $<0.0001$ \\
\hline Personal Care & 0.011 & 0.011 & 0.010 & 0.015 & 0.001 & 0.0085 \\
\hline Other & 0.026 & 0.049 & 0.016 & 0.046 & 0.009 & $<0.0001$ \\
\hline \multicolumn{7}{|l|}{ Real Expenditures on: } \\
\hline Total & 8,052 & 3,930 & 5,077 & 3,083 & 2,976 & $<0.0001$ \\
\hline Housing & 2,009 & 1,498 & 1,274 & 1,024 & 736 & $<0.0001$ \\
\hline Food In & 931 & 533 & 755 & 511 & 176 & $<0.0001$ \\
\hline Food Out & 388 & 388 & 251 & 311 & 137 & $<0.0001$ \\
\hline Transportation & 1,574 & 1,991 & 985 & 1,661 & 589 & $<0.0001$ \\
\hline Utilities & 684 & 341 & 480 & 351 & 204 & $<0.0001$ \\
\hline Furniture/Appliances & 406 & 590 & 244 & 509 & 162 & $<0.0001$ \\
\hline Clothing & 322 & 324 & 194 & 271 & 128 & $<0.0001$ \\
\hline Entertainment & 326 & 440 & 165 & 318 & 161 & $<0.0001$ \\
\hline Health Insurance & 236 & 283 & 0 & 0 & 236 & $<0.0001$ \\
\hline Health Care & 199 & 349 & 113 & 385 & 86 & $<0.0001$ \\
\hline Education & 205 & 596 & 185 & 637 & 21 & 0.0145 \\
\hline Alcohol and Tobacco & 157 & 212 & 156 & 222 & 1 & 0.8771 \\
\hline Home Maintenance & 188 & 429 & 72 & 263 & 116 & $<0.0001$ \\
\hline Interest & 119 & 193 & 57 & 138 & 63 & $<0.0001$ \\
\hline Personal Care & 79 & 78 & 47 & 71 & 32 & $<0.0001$ \\
\hline Other & 227 & 507 & 99 & 347 & 128 & $<0.0001$ \\
\hline Sample n: & \multicolumn{2}{|c|}{16,842} & \multicolumn{4}{|l|}{4,682} \\
\hline
\end{tabular}


Table 4

Expenditures by insurance status and total spending

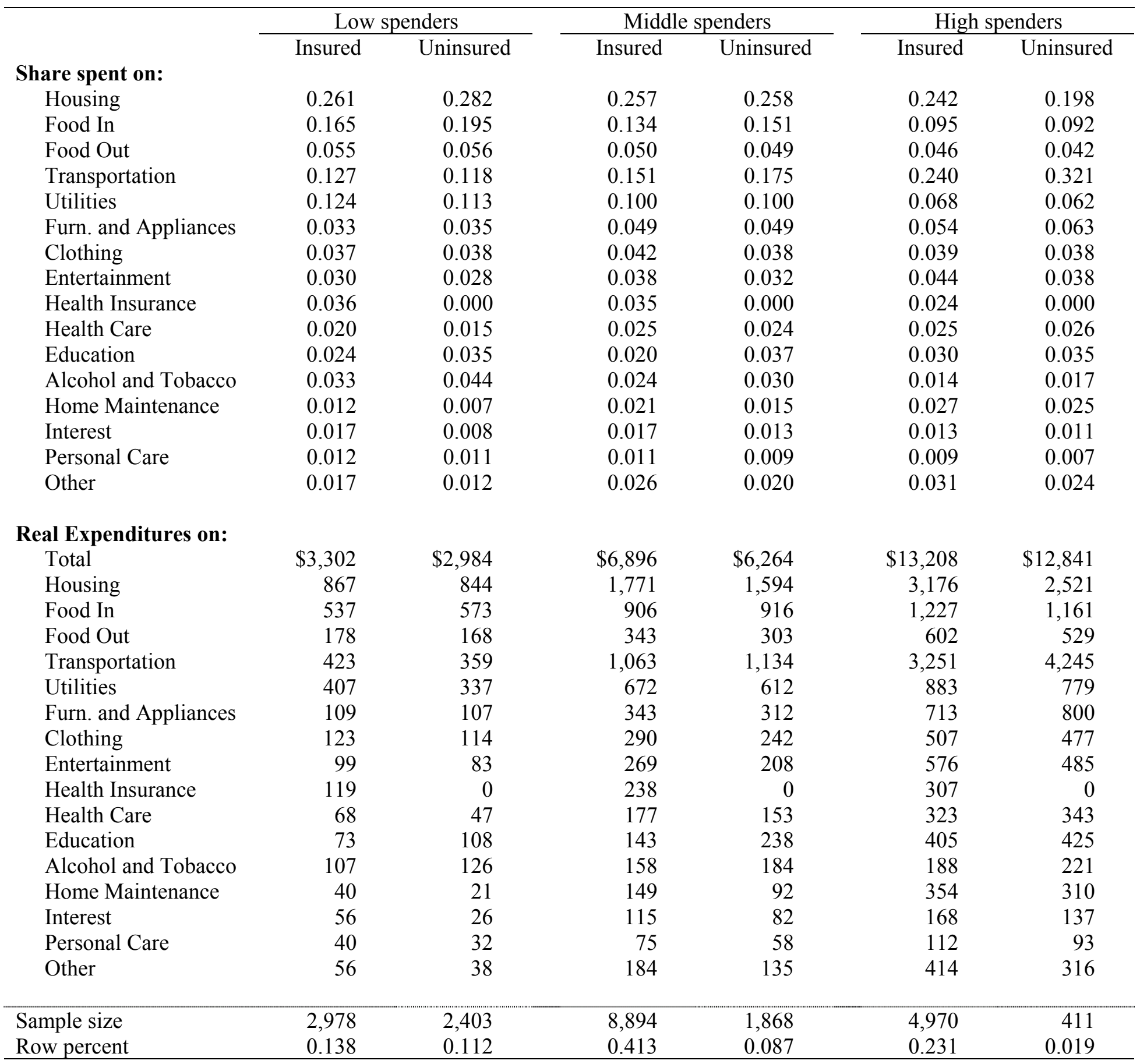


Table 5

Differences in spending: uninsured versus insured, all households

\begin{tabular}{|c|c|c|c|}
\hline $\begin{array}{l}\text { Dependent variable = } \\
\text { Quarterly spending on: }\end{array}$ & $\begin{array}{c}\text { Basic controls } \\
\text { (1) }\end{array}$ & $\begin{array}{c}\text { Work/urban } \\
\text { controls } \\
(2)\end{array}$ & $\begin{array}{c}\text { All controls } \\
(3)\end{array}$ \\
\hline Housing & $\begin{array}{l}-\$ 38 \\
(19)\end{array}$ & $\begin{array}{l}-\$ 43 \\
(20)\end{array}$ & $\begin{array}{c}3 \\
(19)\end{array}$ \\
\hline Food In & $\begin{array}{l}16 \\
(7)\end{array}$ & $\begin{array}{l}10 \\
(8)\end{array}$ & $\begin{array}{c}9 \\
(8)\end{array}$ \\
\hline Food Out & $\begin{array}{l}-6 \\
(6)\end{array}$ & $\begin{array}{l}-11 \\
(6)\end{array}$ & $\begin{array}{l}-17 \\
(6)\end{array}$ \\
\hline Transportation & $\begin{array}{l}231 \\
(26)\end{array}$ & $\begin{array}{l}249 \\
(27)\end{array}$ & $\begin{array}{l}197 \\
(27)\end{array}$ \\
\hline Utilities & $\begin{array}{l}-49 \\
(5)\end{array}$ & $\begin{array}{l}-48 \\
(5)\end{array}$ & $\begin{array}{l}-25 \\
(5)\end{array}$ \\
\hline Furniture/ Appliances & $\begin{array}{l}20 \\
(9)\end{array}$ & $\begin{array}{c}23 \\
(10)\end{array}$ & $\begin{array}{c}27 \\
(10)\end{array}$ \\
\hline Clothing & $\begin{array}{l}-16 \\
(5)\end{array}$ & $\begin{array}{l}-16 \\
(5)\end{array}$ & $\begin{array}{l}-19 \\
(5)\end{array}$ \\
\hline Entertainment & $\begin{array}{l}-8 \\
(7)\end{array}$ & $\begin{array}{l}-6 \\
(7)\end{array}$ & $\begin{array}{l}-4 \\
(7)\end{array}$ \\
\hline Health Insurance & $\begin{array}{l}-190 \\
(4)\end{array}$ & $\begin{array}{c}-199 \\
(5)\end{array}$ & $\begin{array}{c}-200 \\
(5)\end{array}$ \\
\hline Health Care & $\begin{array}{c}6 \\
(6)\end{array}$ & $\begin{array}{c}5 \\
(6)\end{array}$ & $\begin{array}{c}3 \\
(6)\end{array}$ \\
\hline Education & $\begin{array}{c}67 \\
(10)\end{array}$ & $\begin{array}{c}60 \\
(11)\end{array}$ & $\begin{array}{c}46 \\
(11)\end{array}$ \\
\hline Alcohol and Tobacco & $\begin{array}{l}13 \\
(4)\end{array}$ & $\begin{array}{l}11 \\
(4)\end{array}$ & $\begin{array}{c}6 \\
(4)\end{array}$ \\
\hline Home Maintenance & $\begin{array}{l}-7 \\
(7)\end{array}$ & $\begin{array}{l}-5 \\
(7)\end{array}$ & $\begin{array}{c}5 \\
(7)\end{array}$ \\
\hline Interest & $\begin{array}{l}-38 \\
(3)\end{array}$ & $\begin{array}{l}-34 \\
(3)\end{array}$ & $\begin{array}{l}-32 \\
(3)\end{array}$ \\
\hline Personal Care & $\begin{array}{l}-10 \\
(1)\end{array}$ & $\begin{array}{l}-8 \\
(1)\end{array}$ & $\begin{array}{l}-8 \\
(1)\end{array}$ \\
\hline
\end{tabular}




\begin{tabular}{lccc} 
Other & 9 & 12 & 10 \\
& $(8)$ & $(8)$ & $(8)$ \\
\hline Control variables included: & & & \\
Basic & $\mathrm{Y}$ & $\mathrm{Y}$ & $\mathrm{Y}$ \\
$\quad$ Employment and urbanicity & $\mathrm{N}$ & $\mathrm{Y}$ & $\mathrm{Y}$ \\
$\quad$ Housing & $\mathrm{N}$ & $\mathrm{N}$ & $\mathrm{Y}$ \\
Sample n & 21,524 & 20,625 & 20,625 \\
\hline
\end{tabular}


Table 6

Differences in budget shares: uninsured versus insured, low spenders

\begin{tabular}{|c|c|c|c|}
\hline $\begin{array}{l}\text { Dependent variable = } \\
\text { Quarterly spending on: }\end{array}$ & $\begin{array}{l}\text { Basic controls } \\
\text { (1) }\end{array}$ & $\begin{array}{c}\text { Work/urban } \\
\text { controls } \\
(2)\end{array}$ & $\begin{array}{l}\text { All controls } \\
\text { (3) }\end{array}$ \\
\hline Housing & $\begin{array}{l}\$ 88 \\
(13)\end{array}$ & $\begin{array}{l}\$ 80 \\
(14)\end{array}$ & $\begin{array}{c}38 \\
(12)\end{array}$ \\
\hline Food In & $\begin{array}{l}40 \\
(8)\end{array}$ & $\begin{array}{l}34 \\
(8)\end{array}$ & $\begin{array}{l}34 \\
(8)\end{array}$ \\
\hline Food Out & $\begin{array}{c}5 \\
(6)\end{array}$ & $\begin{array}{c}0 \\
(6)\end{array}$ & $\begin{array}{c}2 \\
(6)\end{array}$ \\
\hline Transportation & $\begin{array}{r}-17 \\
(9)\end{array}$ & $\begin{array}{c}-7 \\
(10)\end{array}$ & $\begin{array}{c}1 \\
(10)\end{array}$ \\
\hline Utilities & $\begin{array}{l}-22 \\
(6)\end{array}$ & $\begin{array}{l}-19 \\
(6)\end{array}$ & $\begin{array}{l}-3 \\
(6)\end{array}$ \\
\hline Furniture/ Appliances & $\begin{array}{c}9 \\
(6)\end{array}$ & $\begin{array}{l}11 \\
(6)\end{array}$ & $\begin{array}{l}13 \\
(6)\end{array}$ \\
\hline Clothing & $\begin{array}{l}-2 \\
(4)\end{array}$ & $\begin{array}{c}1 \\
(4)\end{array}$ & $\begin{array}{c}1 \\
(4)\end{array}$ \\
\hline Entertainment & $\begin{array}{l}-4 \\
(4)\end{array}$ & $\begin{array}{l}-3 \\
(4)\end{array}$ & $\begin{array}{l}-1 \\
(4)\end{array}$ \\
\hline Health Insurance & $\begin{array}{c}-111 \\
(3)\end{array}$ & $\begin{array}{l}-114 \\
(4)\end{array}$ & $\begin{array}{l}-112 \\
(4)\end{array}$ \\
\hline Health Care & $\begin{array}{c}0 \\
(4)\end{array}$ & $\begin{array}{l}-2 \\
(4)\end{array}$ & $\begin{array}{l}-2 \\
(4)\end{array}$ \\
\hline Education & $\begin{array}{l}35 \\
(8)\end{array}$ & $\begin{array}{l}35 \\
(8)\end{array}$ & $\begin{array}{l}39 \\
(8)\end{array}$ \\
\hline Alcohol and Tobacco & $\begin{array}{l}20 \\
(5)\end{array}$ & $\begin{array}{l}21 \\
(5)\end{array}$ & $\begin{array}{l}18 \\
(5)\end{array}$ \\
\hline Home Maintenance & $\begin{array}{l}-10 \\
(3)\end{array}$ & $\begin{array}{l}-9 \\
(3)\end{array}$ & $\begin{array}{l}-4 \\
(3)\end{array}$ \\
\hline Interest & $\begin{array}{l}-24 \\
(3)\end{array}$ & $\begin{array}{l}-21 \\
(3)\end{array}$ & $\begin{array}{l}-20 \\
(3)\end{array}$ \\
\hline Personal Care & $\begin{array}{l}-4 \\
(2)\end{array}$ & $\begin{array}{l}-4 \\
(2)\end{array}$ & $\begin{array}{l}-3 \\
(2)\end{array}$ \\
\hline
\end{tabular}




\begin{tabular}{lccc} 
Other & -3 & -1 & 1 \\
& $(3)$ & $(4)$ & $(4)$ \\
\hline Control variables included: & & & \\
Basic & $\mathrm{Y}$ & $\mathrm{Y}$ & $\mathrm{Y}$ \\
Employment and urbanicity & $\mathrm{N}$ & $\mathrm{Y}$ & $\mathrm{Y}$ \\
$\quad$ Housing & $\mathrm{N}$ & $\mathrm{N}$ & $\mathrm{Y}$ \\
Sample n & 5,381 & 4,902 & 4,902 \\
\hline
\end{tabular}


Table 7

Differences in budget shares: uninsured versus insured, middle spenders

\begin{tabular}{|c|c|c|c|}
\hline $\begin{array}{l}\text { Dependent variable = } \\
\text { Quarterly spending on: }\end{array}$ & $\begin{array}{l}\text { Basic controls } \\
\text { (1) }\end{array}$ & $\begin{array}{c}\text { Work/urban } \\
\text { controls } \\
(2)\end{array}$ & $\begin{array}{l}\text { All controls } \\
\text { (3) }\end{array}$ \\
\hline Housing & $\begin{array}{l}-\$ 14 \\
(23)\end{array}$ & $\begin{array}{l}-\$ 21 \\
(24)\end{array}$ & $\begin{array}{c}8 \\
(22)\end{array}$ \\
\hline Food In & $\begin{array}{c}31 \\
(10)\end{array}$ & $\begin{array}{c}26 \\
(10)\end{array}$ & $\begin{array}{c}23 \\
(10)\end{array}$ \\
\hline Food Out & $\begin{array}{l}-1 \\
(8)\end{array}$ & $\begin{array}{l}-3 \\
(8)\end{array}$ & $\begin{array}{l}-12 \\
(8)\end{array}$ \\
\hline Transportation & $\begin{array}{l}172 \\
(23)\end{array}$ & $\begin{array}{l}201 \\
(24)\end{array}$ & $\begin{array}{l}184 \\
(24)\end{array}$ \\
\hline Utilities & $\begin{array}{l}-19 \\
(7)\end{array}$ & $\begin{array}{l}-19 \\
(7)\end{array}$ & $\begin{array}{c}3 \\
(7)\end{array}$ \\
\hline Furniture/ Appliances & $\begin{array}{c}20 \\
(12)\end{array}$ & $\begin{array}{c}22 \\
(12)\end{array}$ & $\begin{array}{c}23 \\
(12)\end{array}$ \\
\hline Clothing & $\begin{array}{l}-24 \\
(6)\end{array}$ & $\begin{array}{l}-21 \\
(7)\end{array}$ & $\begin{array}{l}-26 \\
(7)\end{array}$ \\
\hline Entertainment & $\begin{array}{l}-14 \\
(7)\end{array}$ & $\begin{array}{l}-11 \\
(8)\end{array}$ & $\begin{array}{l}-11 \\
(8)\end{array}$ \\
\hline Health Insurance & $\begin{array}{l}-227 \\
(6)\end{array}$ & $\begin{array}{c}-234 \\
(7)\end{array}$ & $\begin{array}{l}-237 \\
(7)\end{array}$ \\
\hline Health Care & $\begin{array}{l}12 \\
(7)\end{array}$ & $\begin{array}{c}9 \\
(8)\end{array}$ & $\begin{array}{c}7 \\
(8)\end{array}$ \\
\hline Education & $\begin{array}{l}101 \\
(12)\end{array}$ & $\begin{array}{c}86 \\
(13)\end{array}$ & $\begin{array}{c}68 \\
(13)\end{array}$ \\
\hline Alcohol and Tobacco & $\begin{array}{l}25 \\
(5)\end{array}$ & $\begin{array}{l}20 \\
(6)\end{array}$ & $\begin{array}{l}14 \\
(6)\end{array}$ \\
\hline Home Maintenance & $\begin{array}{l}-23 \\
(8)\end{array}$ & $\begin{array}{l}-22 \\
(9)\end{array}$ & $\begin{array}{l}-15 \\
(9)\end{array}$ \\
\hline Interest & $\begin{array}{l}-31 \\
(5)\end{array}$ & $\begin{array}{l}-27 \\
(5)\end{array}$ & $\begin{array}{l}-26 \\
(5)\end{array}$ \\
\hline Personal Care & $\begin{array}{l}-12 \\
(2)\end{array}$ & $\begin{array}{l}-10 \\
(2)\end{array}$ & $\begin{array}{l}-9 \\
(2)\end{array}$ \\
\hline
\end{tabular}




\begin{tabular}{lccc} 
Other & 4 & 5 & 6 \\
& $(9)$ & $(10)$ & $(10)$ \\
\hline Control variables included: & & & \\
Basic & $\mathrm{Y}$ & $\mathrm{Y}$ & $\mathrm{Y}$ \\
Employment and urbanicity & $\mathrm{N}$ & $\mathrm{Y}$ & $\mathrm{Y}$ \\
$\quad$ Housing & $\mathrm{N}$ & $\mathrm{N}$ & $\mathrm{Y}$ \\
Sample n & 10,762 & 10,421 & 10,421 \\
\hline
\end{tabular}


Table 8

Differences in budget shares: uninsured versus insured, high spenders

\begin{tabular}{|c|c|c|c|}
\hline \multirow[b]{2}{*}{$\begin{array}{l}\text { Dependent variable }= \\
\text { Quarterly spending on: }\end{array}$} & \multicolumn{3}{|c|}{ Regression coefficient on "uninsured" dummy } \\
\hline & $\begin{array}{c}\text { Basic controls } \\
\text { (1) }\end{array}$ & $\begin{array}{c}\text { Work/urban } \\
\text { controls } \\
(2)\end{array}$ & $\begin{array}{c}\text { All controls } \\
(3)\end{array}$ \\
\hline Housing & $\begin{array}{l}-419 \\
(89)\end{array}$ & $\begin{array}{l}-406 \\
(91)\end{array}$ & $\begin{array}{l}-220 \\
(85)\end{array}$ \\
\hline Food In & $\begin{array}{c}10 \\
(30)\end{array}$ & $\begin{array}{c}9 \\
(30)\end{array}$ & $\begin{array}{c}7 \\
(31)\end{array}$ \\
\hline Food Out & $\begin{array}{l}-36 \\
(26)\end{array}$ & $\begin{array}{l}-46 \\
(27)\end{array}$ & $\begin{array}{l}-53 \\
(27)\end{array}$ \\
\hline Transportation & $\begin{array}{c}673 \\
(131)\end{array}$ & $\begin{array}{c}668 \\
(133)\end{array}$ & $\begin{array}{c}457 \\
(131)\end{array}$ \\
\hline Utilities & $\begin{array}{l}-58 \\
(17)\end{array}$ & $\begin{array}{l}-61 \\
(17)\end{array}$ & $\begin{array}{l}-26 \\
(17)\end{array}$ \\
\hline Furniture/ Appliances & $\begin{array}{l}102 \\
(44)\end{array}$ & $\begin{array}{c}99 \\
(45)\end{array}$ & $\begin{array}{l}124 \\
(45)\end{array}$ \\
\hline Clothing & $\begin{array}{c}2 \\
(21)\end{array}$ & $\begin{array}{l}-3 \\
(22)\end{array}$ & $\begin{array}{l}-2 \\
(22)\end{array}$ \\
\hline Entertainment & $\begin{array}{l}-39 \\
(33)\end{array}$ & $\begin{array}{l}-34 \\
(33)\end{array}$ & $\begin{array}{l}-21 \\
(34)\end{array}$ \\
\hline Health Insurance & $\begin{array}{l}-293 \\
(17)\end{array}$ & $\begin{array}{l}-312 \\
(17)\end{array}$ & $\begin{array}{l}-317 \\
(17)\end{array}$ \\
\hline Health Care & $\begin{array}{c}41 \\
(29)\end{array}$ & $\begin{array}{l}35 \\
(29)\end{array}$ & $\begin{array}{c}33 \\
(30)\end{array}$ \\
\hline Education & $\begin{array}{c}51 \\
(49)\end{array}$ & $\begin{array}{c}65 \\
(49)\end{array}$ & $\begin{array}{c}15 \\
(48)\end{array}$ \\
\hline Alcohol and Tobacco & $\begin{array}{l}19 \\
(13)\end{array}$ & $\begin{array}{c}17 \\
(13)\end{array}$ & $\begin{array}{c}11 \\
(13)\end{array}$ \\
\hline Home Maintenance & $\begin{array}{c}0 \\
(32)\end{array}$ & $\begin{array}{c}-3 \\
(33)\end{array}$ & $\begin{array}{c}24 \\
(33)\end{array}$ \\
\hline Interest & $\begin{array}{l}-45 \\
(12)\end{array}$ & $\begin{array}{l}-38 \\
(13)\end{array}$ & $\begin{array}{l}-32 \\
(13)\end{array}$ \\
\hline Personal Care & $\begin{array}{l}-12 \\
(4)\end{array}$ & $\begin{array}{l}-10 \\
(5)\end{array}$ & $\begin{array}{l}-9 \\
(5)\end{array}$ \\
\hline
\end{tabular}




\begin{tabular}{lccc} 
Other & 3 & 19 & 9 \\
& $(39)$ & $(39)$ & $(39)$ \\
\hline Control variables included: & & & \\
Basic & $\mathrm{Y}$ & $\mathrm{Y}$ & $\mathrm{Y}$ \\
Employment and urbanicity & $\mathrm{N}$ & $\mathrm{Y}$ & $\mathrm{Y}$ \\
$\quad$ Housing & $\mathrm{N}$ & $\mathrm{N}$ & $\mathrm{Y}$ \\
Sample n & 5,381 & 5,302 & 5,302 \\
\hline
\end{tabular}


Table 9

Detailed housing expenditures for low-expenditure households, by insurance status

Low spenders

\begin{tabular}{lll}
\multicolumn{2}{c}{ Insured } & \multicolumn{2}{c}{ Uninsured } \\
Mean SD & Mean SD
\end{tabular}

\section{Share of total expenditures on:}

Housing (total)

1. Rent and ownership expenses
1a. Rent
1b. Tenant's insurance
1c. Housing for someone at school
1d. Lodging while on trips
1e. Rent received as pay

2. Property taxes

3. Mortgage principal payments

4. Mortgage interest payments

5. Special and lump-sum mortgage payments

6. Home construction and improvement

$\begin{array}{llll}0.261 & 0.149 & 0.282 & 0.163 \\ 0.199 & 0.172 & 0.249 & 0.179 \\ 0.180 & 0.176 & 0.230 & 0.181 \\ 0.007 & 0.019 & 0.003 & 0.013 \\ 0.005 & 0.041 & 0.008 & 0.044 \\ 0.004 & 0.012 & 0.002 & 0.009 \\ 0.002 & 0.022 & 0.007 & 0.041 \\ 0.022 & 0.044 & 0.012 & 0.038 \\ 0.012 & 0.036 & 0.007 & 0.028 \\ 0.025 & 0.071 & 0.014 & 0.055 \\ 0.000 & 0.007 & 0.000 & 0.004 \\ 0.002 & 0.015 & 0.001 & 0.007\end{array}$

\section{Real expenditures on:}

Housing (total)

1. Rent and ownership expenses
1a. Rent
1b. Tenant's insurance
1c. Housing for someone at school
1d. Lodging while on trips
1e. Rent received as pay

2. Property taxes

3. Mortgage principal payments

4. Mortgage interest payments

5. Special and lump-sum mortgage payments

6. Home construction and improvement

$\begin{array}{rrrr}\$ 867 & \$ 528 & \$ 844 & \$ 531 \\ 651 & 584 & 736 & 562 \\ 592 & 594 & 678 & 563 \\ 24 & 61 & 9 & 41 \\ 15 & 117 & 22 & 134 \\ 12 & 41 & 6 & 26 \\ 8 & 78 & 21 & 125 \\ 74 & 146 & 37 & 117 \\ 43 & 126 & 22 & 93 \\ 91 & 261 & 46 & 193 \\ 2 & 24 & 0 & 16 \\ 6 & 49 & 2 & 25\end{array}$

\section{Number of rooms}

$\begin{array}{llll}4.7 & 1.7 & 4.3 & 1.8\end{array}$

\section{Housing tenure}

Own home, no mortgage

Own home, with mortgage

Rent

Occupy home rent-free

Live in dormitory

$\begin{array}{llll}0.170 & 0.376 & 0.081 & 0.273 \\ 0.208 & 0.406 & 0.117 & 0.321 \\ 0.555 & 0.497 & 0.692 & 0.462 \\ 0.026 & 0.160 & 0.051 & 0.220 \\ 0.040 & 0.196 & 0.059 & 0.235\end{array}$


Table 10

Detailed housing expenditures for low-expenditure households

By insurance and homeownership status

\begin{tabular}{|c|c|c|c|c|c|c|}
\hline & \multicolumn{2}{|c|}{$\begin{array}{l}\text { Homeowners: } \\
\text { No mortgage }\end{array}$} & \multicolumn{2}{|c|}{$\begin{array}{l}\text { Homeowners: } \\
\text { With mortgage }\end{array}$} & \multicolumn{2}{|c|}{ Renters } \\
\hline & Insured & Uninsured & Insured & Uninsured & Insured & Uninsured \\
\hline \multicolumn{7}{|l|}{ Share of total expenditures on: } \\
\hline Housing (total) & 0.106 & 0.118 & 0.294 & 0.322 & 0.304 & 0.302 \\
\hline 1. Rent and ownership expenses & 0.033 & 0.039 & 0.026 & 0.034 & 0.301 & 0.301 \\
\hline 1a. Rent & 0.010 & 0.027 & 0.005 & 0.015 & 0.285 & 0.281 \\
\hline 1b. Tenant's insurance & 0.018 & 0.011 & 0.017 & 0.016 & 0.001 & 0.000 \\
\hline 1c. Housing for someone at school & 0.000 & 0.000 & 0.000 & 0.000 & 0.008 & 0.009 \\
\hline 1d. Lodging while on trips & 0.004 & 0.002 & 0.003 & 0.002 & 0.003 & 0.002 \\
\hline 1e. Rent received as pay & 0.000 & 0.000 & 0.000 & 0.000 & 0.004 & 0.009 \\
\hline 2. Property taxes & 0.065 & 0.069 & 0.048 & 0.048 & 0.001 & 0.000 \\
\hline 3. Mortgage principal payments & 0.001 & 0.001 & 0.07 & 0.079 & 0.000 & 0.000 \\
\hline 4. Mortgage interest payments & 0.002 & 0.003 & 0.144 & 0.16 & 0.001 & 0.000 \\
\hline 5. Special mortgage payments & 0.000 & 0.001 & 0.002 & 0.001 & 0.000 & 0.000 \\
\hline 6. Home construction and improvement & 0.005 & 0.005 & 0.004 & 0.001 & 0.000 & 0.000 \\
\hline \multicolumn{7}{|l|}{ Real expenditures on: } \\
\hline Housing (total) & $\$ 337$ & $\$ 348$ & $\$ 1,041$ & $\$ 1,082$ & $\$ 996$ & $\$ 892$ \\
\hline 1. Rent and ownership expenses & 104 & 114 & 90 & 110 & 989 & 890 \\
\hline 1a. Rent & 34 & 78 & 18 & 48 & 936 & 829 \\
\hline 1b. Tenant's insurance & 55 & 31 & 61 & 54 & 3 & 1 \\
\hline 1c. Housing for someone at school & 0 & 0 & 0 & 0 & 24 & 28 \\
\hline 1d. Lodging while on trips & 15 & 5 & 11 & 8 & 12 & 6 \\
\hline 1e. Rent received as pay & 0 & 1 & 0 & 0 & 14 & 26 \\
\hline 2. Property taxes & 206 & 201 & 171 & 159 & 3 & 1 \\
\hline 3. Mortgage principal payments & 3 & 4 & 244 & 259 & 1 & 0 \\
\hline 4. Mortgage interest payments & 7 & 11 & 513 & 549 & 3 & 1 \\
\hline 5. Special mortgage payments & 1 & 2 & 8 & 2 & 0 & 0 \\
\hline 6. Home construction and improvement & 16 & 16 & 15 & 4 & 0 & 0 \\
\hline Number of rooms & 5.5 & 5.2 & 5.5 & 5.3 & 4.2 & 4.1 \\
\hline Unweighted sample size & 577 & 267 & 465 & 184 & 1,936 & 1,952 \\
\hline
\end{tabular}


Table 11

Housing expenditures for low-expenditure households: insured versus uninsured

Dependent variable:

Housing (total)

Components of housing expenditures:

1. Rent and ownership expenses

1a. Rent

1b. Tenant's insurance

1c. Housing for someone at school

1d. Lodging while on trips

1e. Rent received as pay

2. Property taxes

3. Mortgage principal payments

4. Mortgage interest payments

5. Special and lump-sum mortgage payments

6. Home construction and improvement

\begin{tabular}{ccc}
\hline \multicolumn{3}{c}{ Real spending } \\
\hline Basic & Work/urban & All \\
controls & controls & controls
\end{tabular}

(1)

$\$ 88$

(13)

129

(15)

122

(15)

(2)

$\$ 80$

(14)

(3)

$\$ 38$

(12)

131

(16)

20

130

(16)

15

$-8$

(2)

$-9$

(2)

$-4$

(2)

$4 \quad 0$

(4) (3)

3

$-4$

(1)

$-3$

(1)

$-3$

15

(3)

13

(3)

(1)

$-13$

(4)

$-18$

(4)

(3)

$-9 \quad-11$

(3)

(2)

(3)

$-16$

(7)

$-20$

(7)

12

(5)

0

(1)

0

(1)

(1)

$\begin{array}{ll}-3 & -2\end{array}$

(1)

(1)

(1)

\begin{tabular}{llll}
\hline Number of rooms & -0.3 & -0.3 & -0.1 \\
& $(0.1)$ & $(0.1)$ & $(0.1)$ \\
\hline Control variables included in specification: & & & \\
Basic & $\mathrm{Y}$ & $\mathrm{Y}$ & $\mathrm{Y}$ \\
Employment and urbanicity & $\mathrm{N}$ & $\mathrm{Y}$ & $\mathrm{Y}$ \\
Housing & $\mathrm{N}$ & $\mathrm{N}$ & $\mathrm{Y}$ \\
Sample $\mathrm{n}$ & 5,381 & 4,902 & 4,902 \\
\hline
\end{tabular}


Table 12

Transportation expenditures of the highest spending quartile: insured versus uninsured

\begin{tabular}{lrrrr} 
& \multicolumn{2}{c}{ Insured } & \multicolumn{2}{c}{ Uninsured } \\
& Mean & SD & Mean & SD \\
\hline & & & & \\
Share of total expenditures on: & & & & \\
$\quad$ Transportation (total) & 0.240 & 0.191 & 0.321 & 0.253 \\
1. Leased vehicles & 0.013 & 0.045 & 0.010 & 0.043 \\
2. New vehicles & 0.059 & 0.158 & 0.064 & 0.181 \\
3.Used vehicles & 0.070 & 0.153 & 0.157 & 0.244 \\
4.Other private transportation & & & & \\
$\quad$ (Registration fees, tolls, rental cars, etc.) & 0.007 & 0.011 & 0.007 & 0.012 \\
5. Fuel and oil & 0.033 & 0.020 & 0.033 & 0.028 \\
6.Vehicle maintenance and repair & 0.019 & 0.027 & 0.018 & 0.030 \\
7. Vehicle insurance & 0.024 & 0.021 & 0.021 & 0.021 \\
8. Public transportation (includes airfares) & 0.014 & 0.027 & 0.013 & 0.026 \\
& & & & \\
Real expenditures on: & & & & \\
Transportation (total) & $\$ 3,251$ & $\$ 2,839$ & $\$ 4,245$ & $\$ 3,590$ \\
1. Leased vehicles & 178 & 606 & 136 & 562 \\
2. New vehicles & 848 & 2320 & 878 & 2511 \\
3.Used vehicles & 961 & 2155 & 2081 & 3350 \\
4.Other private transportation & & & & \\
$\quad$ (Registration fees, tolls, rental cars, etc.) & 96 & 150 & 84 & 161 \\
5. Fuel and oil & 425 & 247 & 419 & 432 \\
6.Vehicle maintenance and repair & 249 & 348 & 224 & 400 \\
7. Vehicle insurance & 313 & 274 & 262 & 261 \\
8. Public transportation (includes airfares) & 181 & 362 & 161 & 332 \\
& & & & \\
Number of vehicles & 2.7 & 1.8 & 2.2 & 1.5 \\
Unweighted sample size & & & & \\
& 4,970 & & & 411 \\
\hline
\end{tabular}


Table 13

Transportation expenditures for high-expenditure households: insured versus uninsured

Dependent variable:

Transportation (total)

1. Leased vehicles

2. New vehicles

3.Used vehicles

4.Other private transportation

5. Fuel and oil

6.Vehicle maintenance and repair

7. Vehicle insurance

8. Public transportation (includes airfares)
Total expenditure as control

Work/

Basic urban All controls controls controls

(1)

\section{$\$ 673$}

(131)

$-25$

(31)

$-125$

(115)

865

(113)

$-5$

(8)

6

(13)

$-3$

(18)

$-42$

(14)

3

(18)
(2)

$\$ 668$

(133)

\section{$\$ 457$}

(131)

$$
-32
$$

(32)

$-38$

(32)

$\begin{array}{ll}-216 & -270\end{array}$

(116)

(116)

$934 \quad 795$

(115)

(115)

$-4$

(8)

$-7$

(8)

$18 \quad 25$

(13)

(13)

(19)

(19)

$-39$

(14)

(14)

$6 \quad-3$

(19)

(19)

\begin{tabular}{ccc}
\multicolumn{3}{c}{ Income as control } \\
\hline Work/ \\
Basic & urban & All \\
controls & controls & controls \\
$(4)$ & $(5)$ & $(6)$
\end{tabular}

$\$ 430$

(146)

$\$ 435$

$\$ 289$

(148)

(147)

$-21$

$-30$

(32)

$-35$

(31)

(33)

$-269$

(120)

$-343$

(120)

$-366$

(121)

\section{6}

811

(118)

704

(115)

(118)

1

(8)

(8)

$-3$

(8)

12

21

(13)

27

(13)

(13)

$-1$

(18)

1
$(19)$

$-3$

(19)

$-38$

(14)

$-36$

(14)

$-37$

(14)

$\begin{array}{rrr}10 & 12 & 3 \\ (18) & (19) & (19)\end{array}$

\section{$-0.4$}

$(0.1)$

Control variables included in specification:

Basic (with total expenditure)

Basic (with income instead of exp.)

Employment and urbanicity

Housing

$\begin{array}{lll}-0.4 & -0.3 & -0.3 \\ (0.1) & (0.1) & (0.1) \\ \mathrm{Y} & \mathrm{Y} & \mathrm{Y} \\ \mathrm{N} & \mathrm{N} & \mathrm{N} \\ \mathrm{N} & \mathrm{Y} & \mathrm{Y} \\ \mathrm{N} & \mathrm{N} & \mathrm{Y}\end{array}$

$\begin{array}{cc}-0.3 & -0.3 \\ (0.1) & (0.1) \\ & \\ \mathrm{Y} & \mathrm{Y} \\ \mathrm{N} & \mathrm{N} \\ \mathrm{Y} & \mathrm{Y} \\ \mathrm{N} & \mathrm{Y}\end{array}$

$-3$

9)

5,302

5,381

-0.4
$(0.1)$

$-0.3$

$\begin{array}{lll}\mathrm{N} & \mathrm{N} & \mathrm{N} \\ \mathrm{Y} & \mathrm{Y} & \mathrm{Y} \\ \mathrm{N} & \mathrm{Y} & \mathrm{Y} \\ \mathrm{N} & \mathrm{N} & \mathrm{Y}\end{array}$


Table 14

Share of spending on "basic needs", by total expenditure level

\begin{tabular}{|c|c|c|c|c|c|c|}
\hline \multirow[b]{2}{*}{ Total } & \multicolumn{2}{|c|}{$\begin{array}{l}\text { Cumulative column } \\
\text { fractions: }\end{array}$} & \multirow{2}{*}{$\begin{array}{l}\text { Fraction } \\
\text { insured: } \\
\\
0.778\end{array}$} & \multicolumn{2}{|c|}{ Share on "basic needs" } & \multirow{2}{*}{$\begin{array}{l}\begin{array}{l}\text { Share on HI } \\
\text { (for insured) } \\
0.032\end{array} \\
\end{array}$} \\
\hline & $\begin{array}{l}\text { Total } \\
1.00\end{array}$ & $\begin{array}{c}\text { Uninsured } \\
1.00\end{array}$ & & $\frac{\text { Uninsured }}{0.539}$ & $\frac{\text { Insured }}{0.477}$ & \\
\hline$\$ 2,000$ & 0.020 & 0.063 & 0.303 & 0.604 & 0.504 & 0.035 \\
\hline$\$ 2,500$ & 0.059 & 0.162 & 0.437 & 0.602 & 0.564 & 0.031 \\
\hline$\$ 3,000$ & 0.105 & 0.269 & 0.485 & 0.600 & 0.554 & 0.037 \\
\hline$\$ 3,500$ & 0.162 & 0.380 & 0.568 & 0.581 & 0.568 & 0.033 \\
\hline$\$ 4,000$ & 0.221 & 0.474 & 0.645 & 0.586 & 0.538 & 0.038 \\
\hline$\$ 4,500$ & 0.280 & 0.560 & 0.675 & 0.560 & 0.535 & 0.039 \\
\hline$\$ 5,000$ & 0.334 & 0.625 & 0.737 & 0.561 & 0.534 & 0.036 \\
\hline$\$ 5,500$ & 0.391 & 0.677 & 0.795 & 0.550 & 0.518 & 0.040 \\
\hline$\$ 6,000$ & 0.446 & 0.728 & 0.793 & 0.515 & 0.509 & 0.037 \\
\hline$\$ 6,500$ & 0.495 & 0.768 & 0.820 & 0.516 & 0.500 & 0.039 \\
\hline$\$ 7,000$ & 0.543 & 0.801 & 0.847 & 0.463 & 0.484 & 0.036 \\
\hline$\$ 7,500$ & 0.589 & 0.835 & 0.840 & 0.471 & 0.483 & 0.034 \\
\hline$\$ 8,000$ & 0.630 & 0.856 & 0.887 & 0.466 & 0.474 & 0.035 \\
\hline$\$ 8,500$ & 0.668 & 0.877 & 0.877 & 0.464 & 0.474 & 0.033 \\
\hline$\$ 9,000$ & 0.702 & 0.891 & 0.909 & 0.464 & 0.469 & 0.030 \\
\hline$\$ 9,500$ & 0.735 & 0.907 & 0.888 & 0.427 & 0.454 & 0.029 \\
\hline$\$ 10,000$ & 0.763 & 0.918 & 0.915 & 0.388 & 0.443 & 0.028 \\
\hline$\$ 10,500$ & 0.787 & 0.929 & 0.898 & 0.354 & 0.439 & 0.028 \\
\hline$\$ 10,500+$ & 1.000 & 1.000 & 0.926 & 0.352 & 0.400 & 0.023 \\
\hline
\end{tabular}


Table 15

Share of expenditures on basic needs or necessities other than health insurance

Dependent variable:

\begin{tabular}{ccccc}
\hline & & & \multicolumn{2}{c}{$\begin{array}{c}\text { Share on necessities other } \\
\text { than health insurance }\end{array}$} \\
\cline { 1 - 1 } \cline { 5 - 5 } Coeff. & SE & & Coeff. & SE \\
0.08365 & 0.00482 & & 0.07657 & 0.00472 \\
-0.00002 & $<0.00001$ & & -0.00002 & $<0.00001$ \\
& & & & \\
-0.00001 & $<0.00001$ & & -0.00001 & $<0.00001$ \\
0.01841 & 0.00289 & & 0.00309 & 0.00283 \\
-0.00941 & 0.00353 & & -0.00267 & 0.00345 \\
-0.02190 & 0.00359 & & -0.01114 & 0.00352 \\
0.00672 & 0.00398 & & 0.01562 & 0.00390 \\
0.00904 & 0.00450 & & 0.00987 & 0.00441 \\
0.00168 & 0.00009 & & 0.00118 & 0.00009 \\
0.00082 & 0.00257 & & -0.00227 & 0.00252 \\
0.01163 & 0.00198 & & 0.01269 & 0.00194 \\
0.02361 & 0.00195 & & 0.02073 & 0.00191 \\
0.03086 & 0.00168 & & 0.02342 & 0.00165 \\
0.03040 & 0.00171 & & 0.02503 & 0.00167 \\
0.03256 & 0.00375 & & 0.01707 & 0.00368
\end{tabular}

Notes:

1. Sample size for both regressions is 21,524 .

2. "Basic needs" are defined as food at home, housing and utilities.

3. Necessities are defined as food at home, food away from home, housing, utilities, alcohol and tobacco, interest, personal care and health care (i.e. all goods with elasticities with respect to total spending less than or equal to one, except for health insurance). 
Figure 1

Regression-adjusted spending differentials: uninsured - insured households

All households

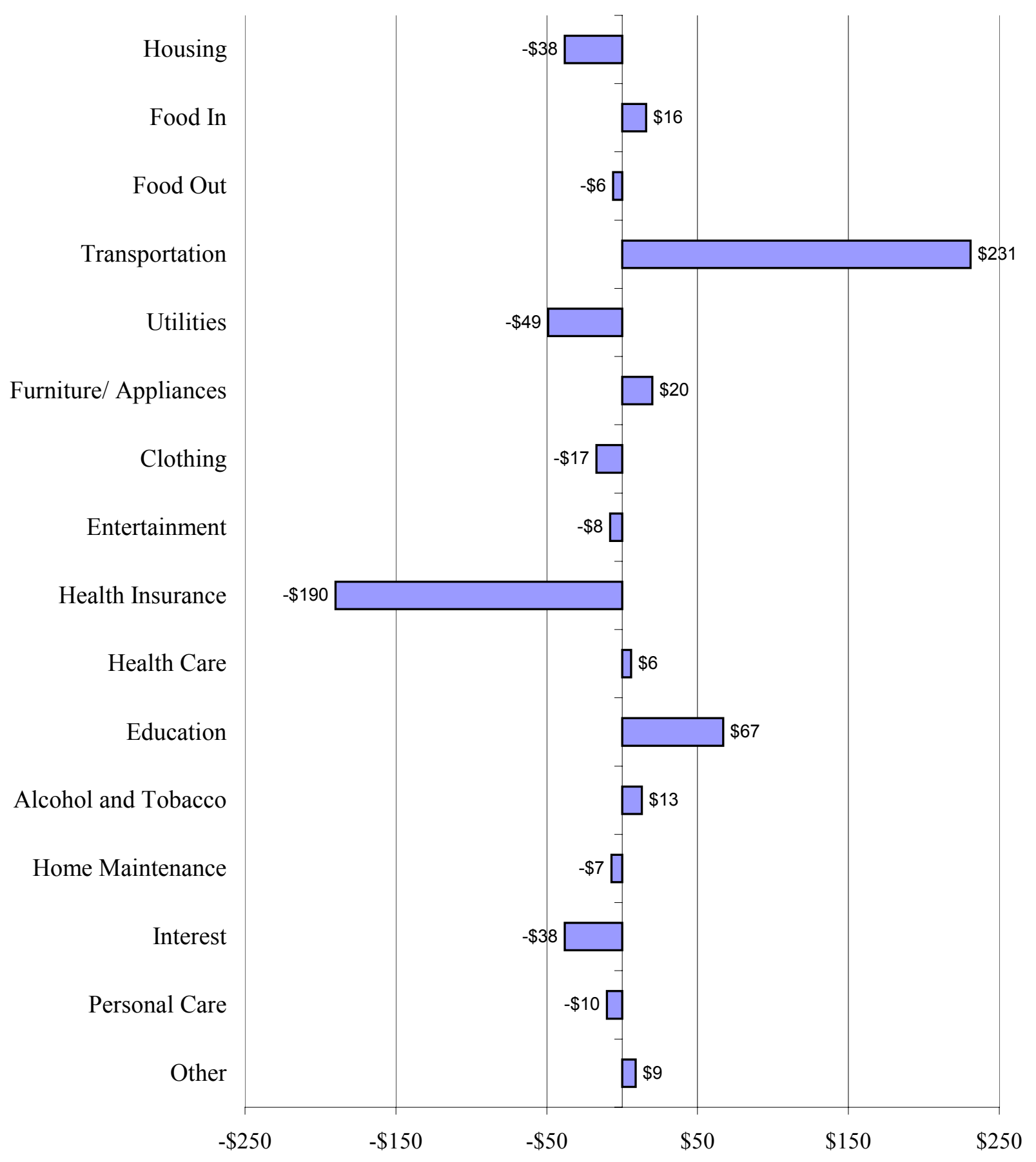


Figure 2

Regression-adjusted spending differentials: uninsured - insured households Lowest quartile of spenders

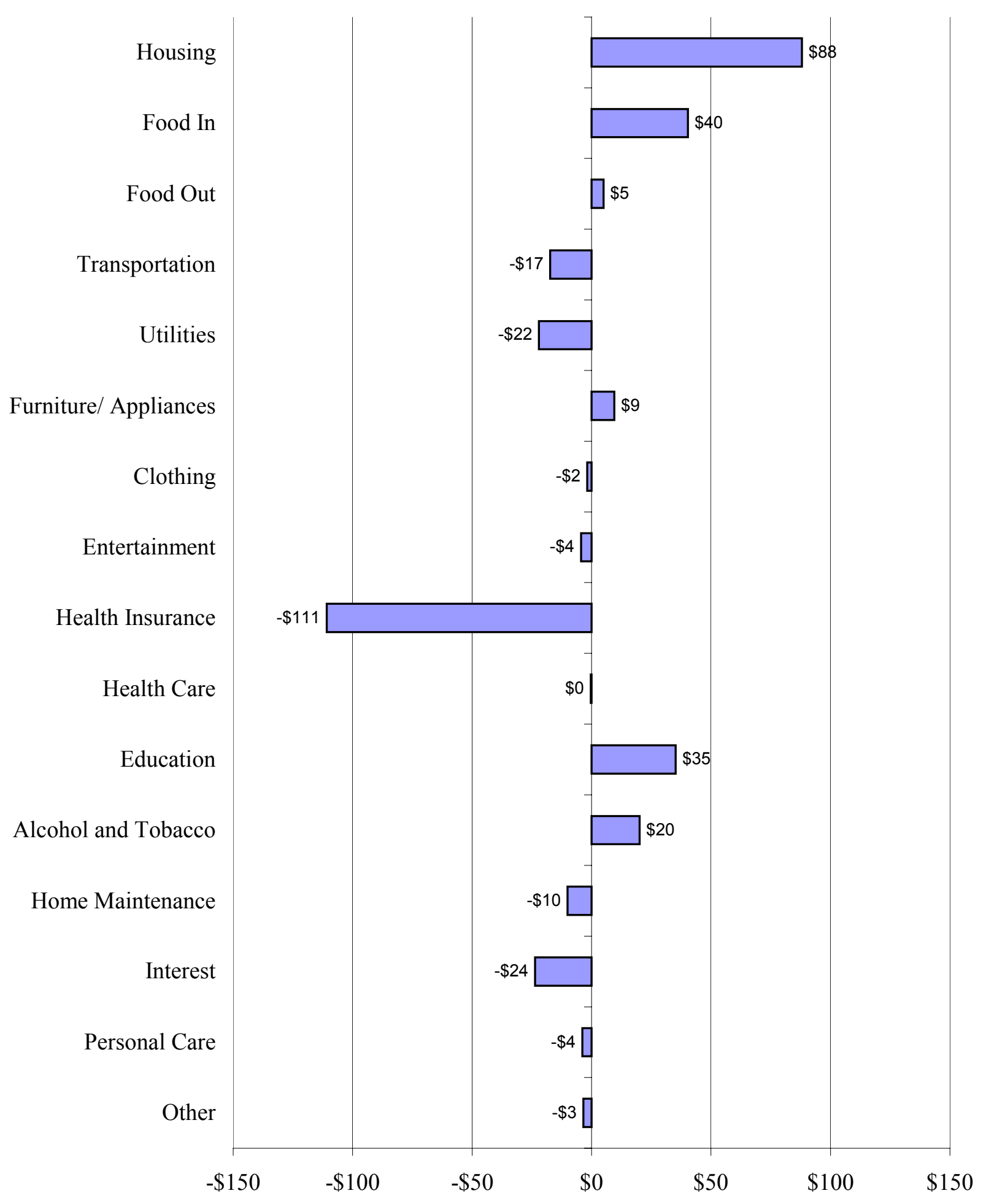


Figure 3

Regression-adjusted spending differentials: uninsured - insured households Middle two quartiles of spenders

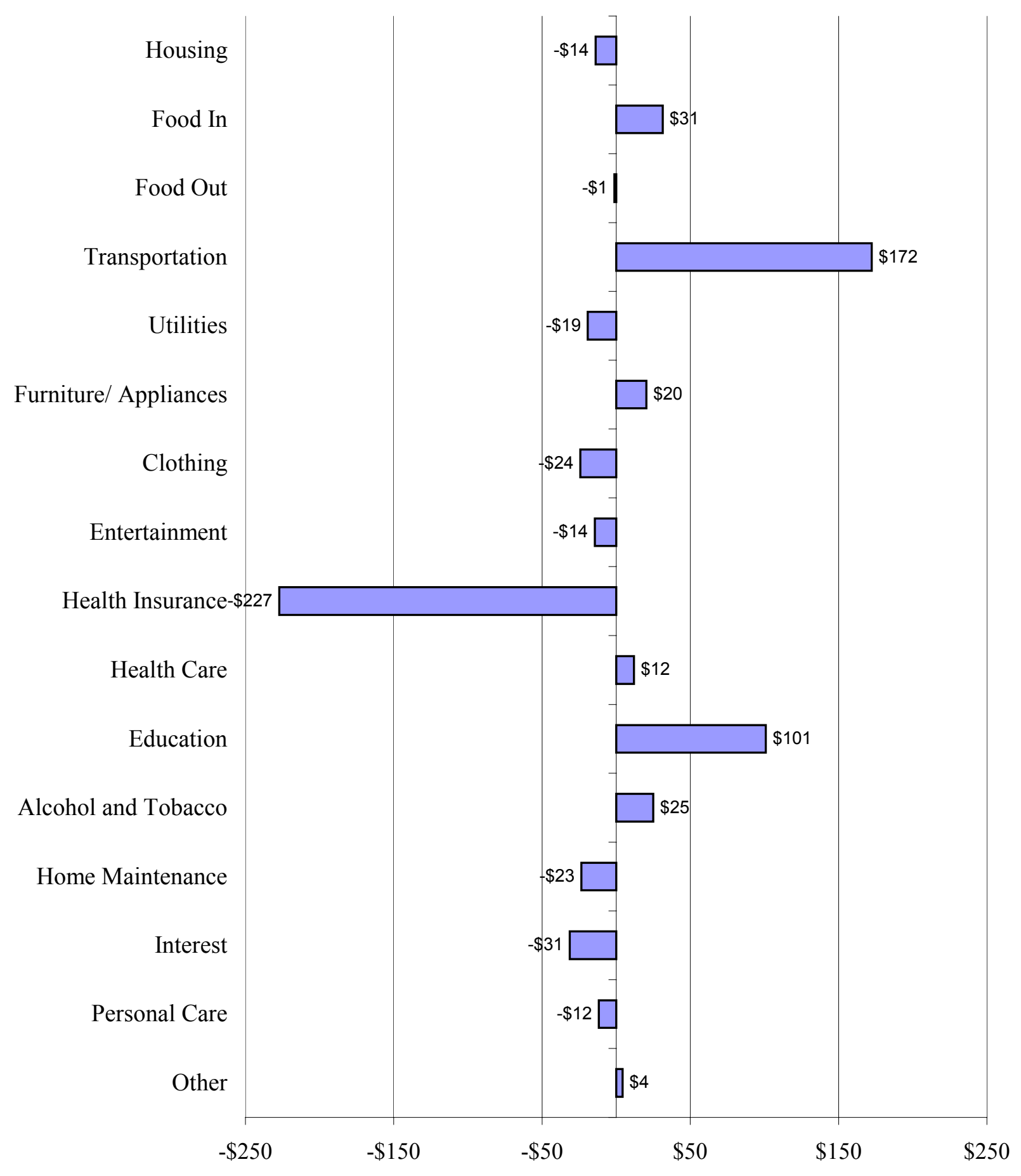


Figure 4

Regression-adjusted spending differentials: uninsured - insured households Highest quartile of spenders

Housing

Food In

Food Out

Transportation

Utilities

Furniture/ Appliances

Clothing

Entertainment

Health Insurance

Health Care

Education

Alcohol and Tobacco

Home Maintenance

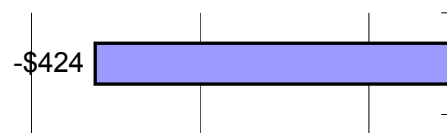

Transportation

(n)


Figure 5

At what point does health insurance replace basic needs?

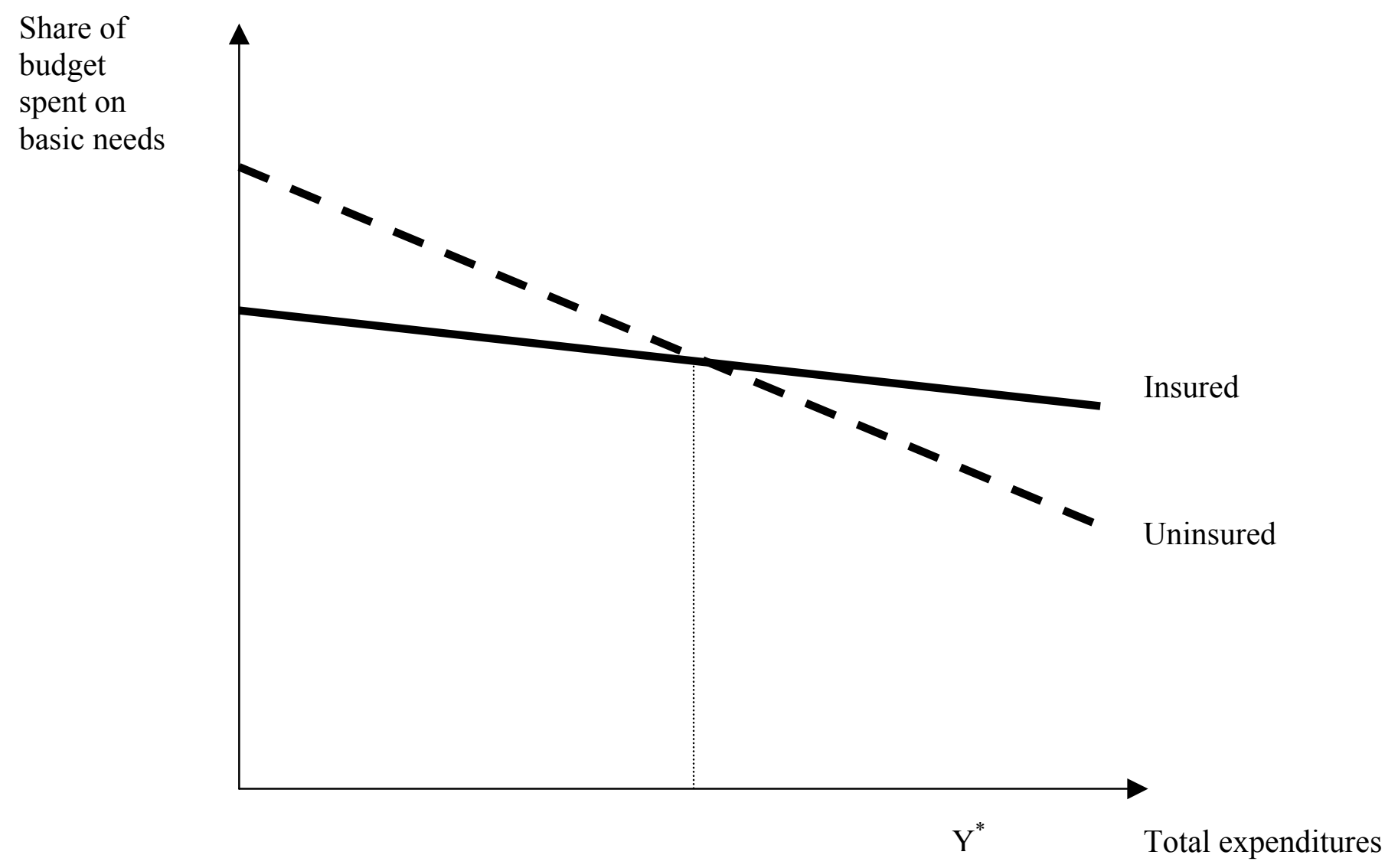

$\mathrm{Y}^{*}$ is the level of total expenditures at which the uninsured devote a smaller share of their budget to basic needs than do comparable insured households. 


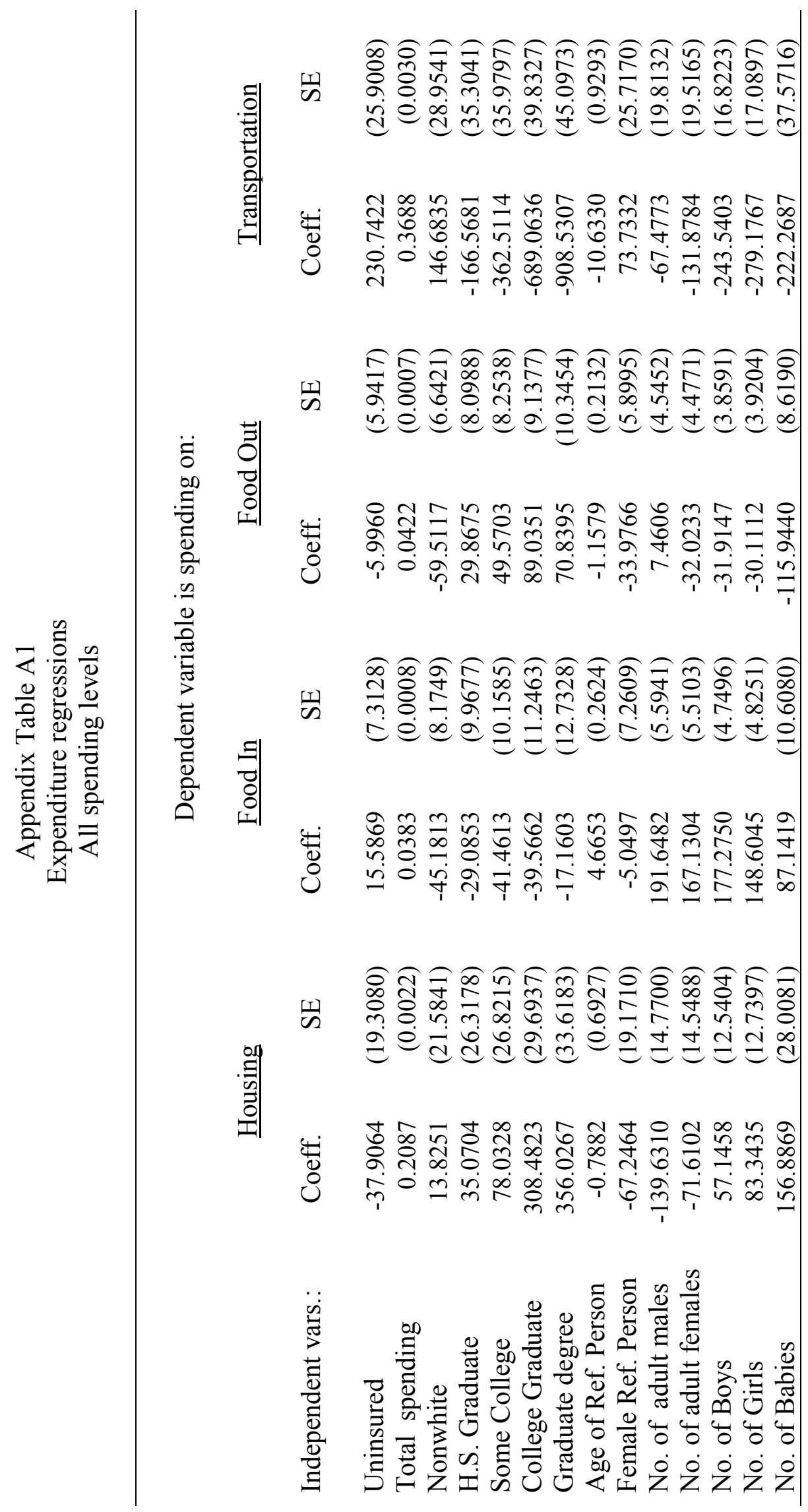




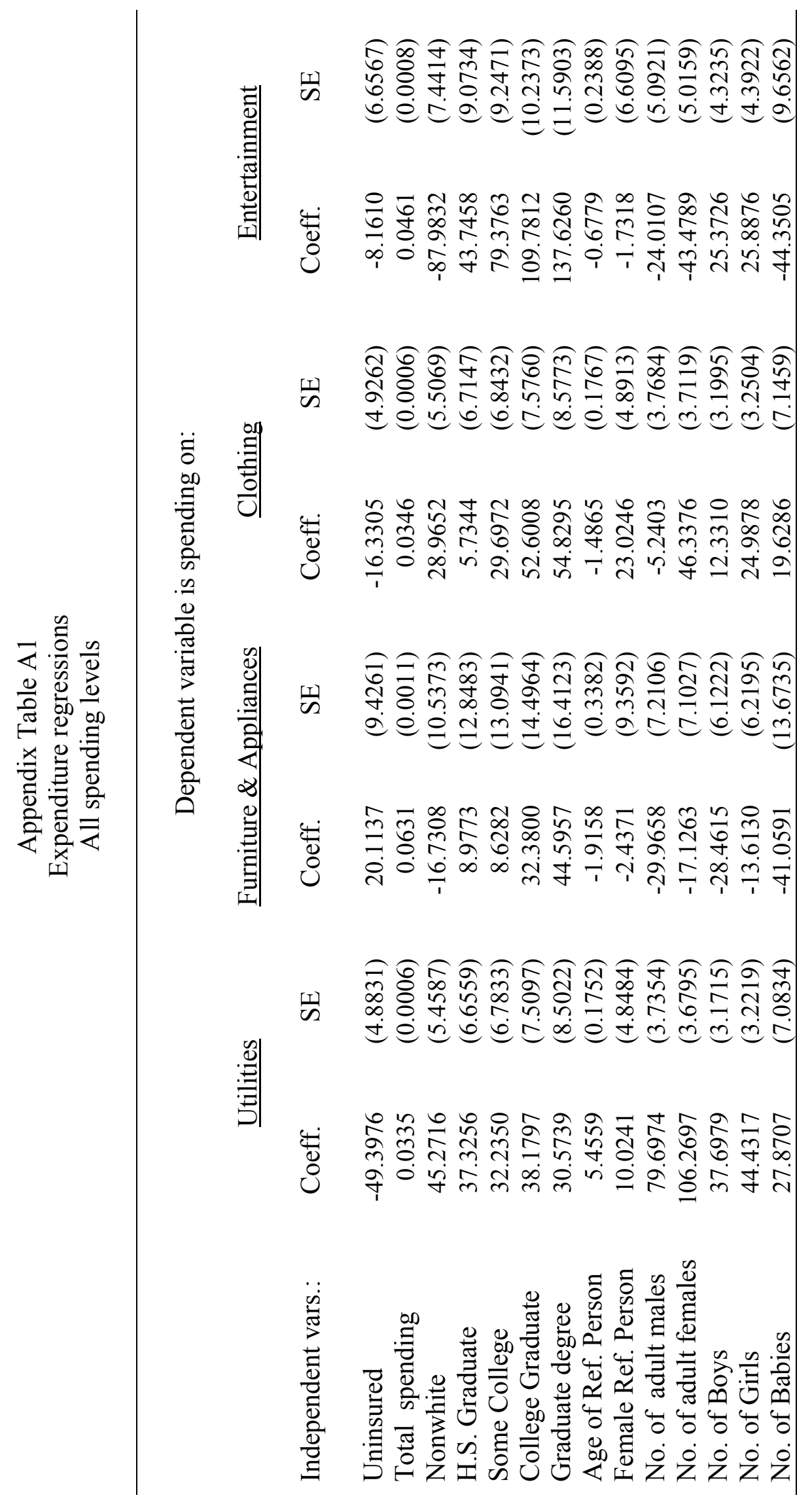




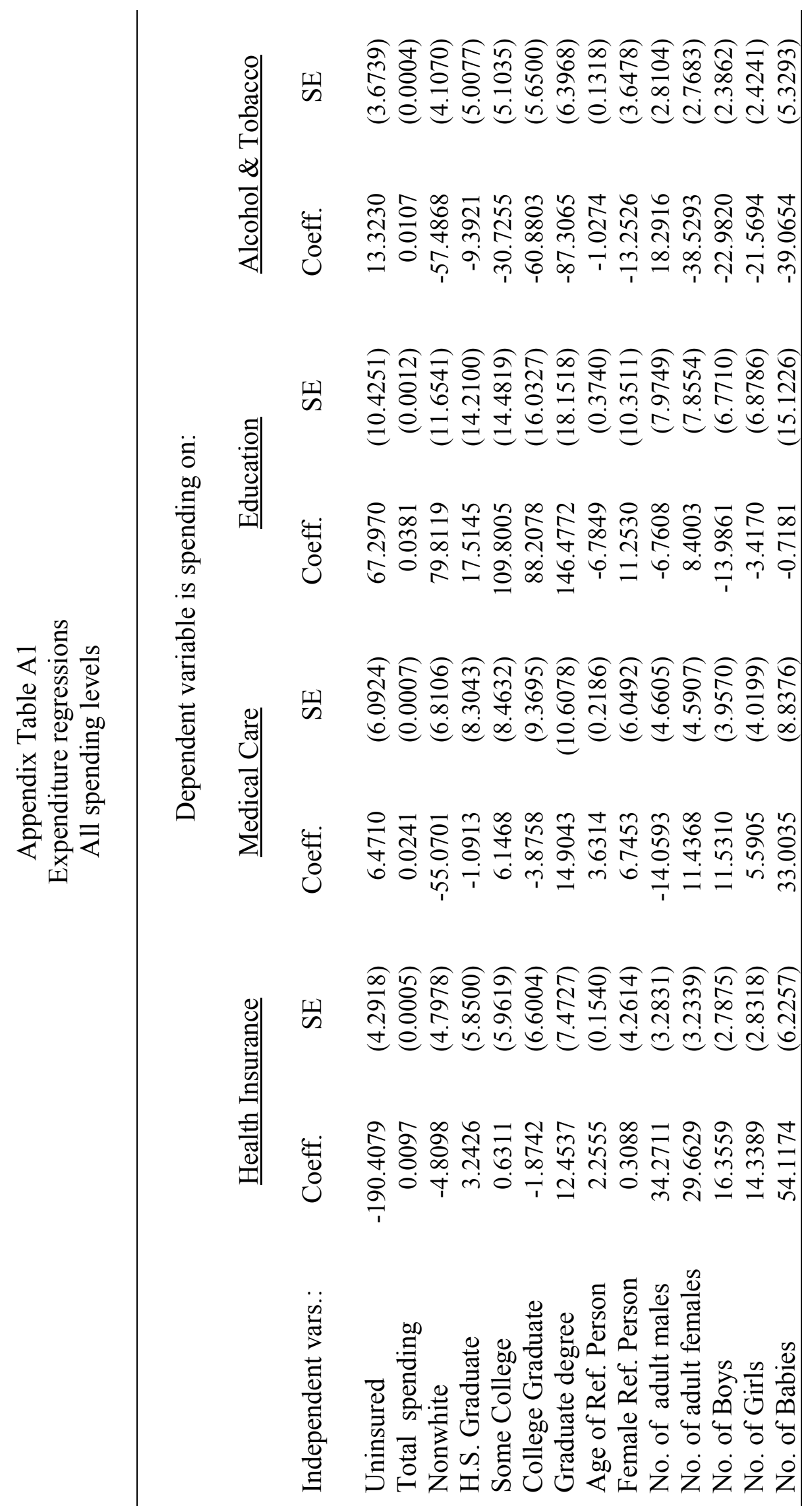




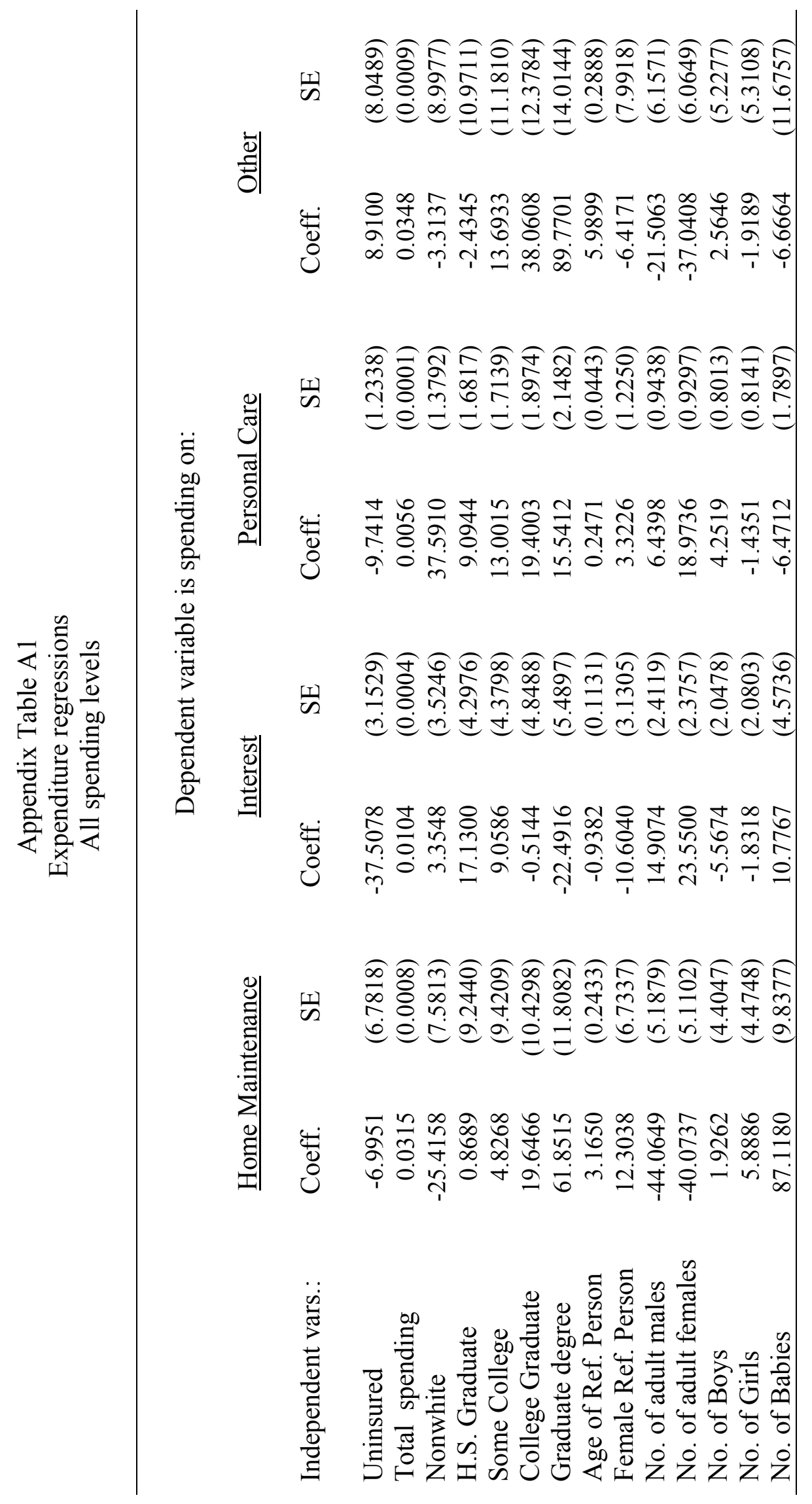


Appendix Table A2

Expenditure elasticities for different goods

\section{Elasticity}

\begin{tabular}{ll} 
Food In & 0.317 \\
Utilities & 0.388 \\
Health Insurance & 0.390 \\
Alcohol and Tobacco & 0.504 \\
Personal Care & 0.572 \\
Housing & 0.835 \\
Interest & 0.730 \\
Food Out & 0.873 \\
Clothing & 0.870 \\
Health Care & 0.992 \\
\hline Entertainment & 1.173 \\
Furniture and Appliances & 1.259 \\
Other & 1.296 \\
Home Maintenance & 1.432 \\
Education & 1.401 \\
Transportation & 1.888 \\
\hline
\end{tabular}

Source: Author's calculations from CEX data. 